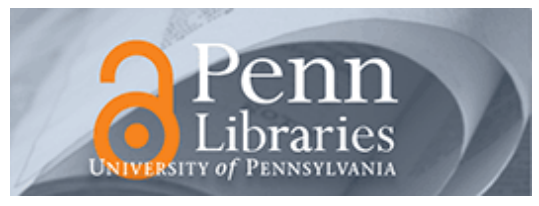

University of Pennsylvania

ScholarlyCommons

Accounting Papers

Wharton Faculty Research

$4-2015$

\title{
Alternative Information Sources and Information Asymmetry Reduction: Evidence From Small Business Debt
}

Gavin Cassar

Christopher D. Ittner

University of Pennsylvania

Ken S. Cavalluzzo

Follow this and additional works at: https://repository.upenn.edu/accounting_papers

Part of the Accounting Commons, and the Economics Commons

\section{Recommended Citation}

Cassar, G., Ittner, C. D., \& Cavalluzzo, K. S. (2015). Alternative Information Sources and Information Asymmetry Reduction: Evidence From Small Business Debt. Journal of Accounting and Economics, 59 (2-3), 242-263. http://dx.doi.org/10.1016/j.jacceco.2014.08.003

This paper is posted at ScholarlyCommons. https://repository.upenn.edu/accounting_papers/17

For more information, please contact repository@pobox.upenn.edu. 


\title{
Alternative Information Sources and Information Asymmetry Reduction: Evidence From Small Business Debt
}

\author{
Abstract \\ We examine whether more sophisticated accounting methods (in the form of accrual accounting) interact \\ with other information sources to reduce information asymmetries between small business borrowers \\ and lenders, thereby lowering borrowers' probability of loan denial and cost of debt. We find that higher \\ third party credit scores, but not the use of accrual accounting, decrease the likelihood of loan denial. \\ However, firms using accrual accounting exhibit statistically lower interest rates after controlling for many \\ factors associated with the cost of debt. Further, the interest rate benefits from accrual accounting are \\ greatest when the borrower's credit score is low and/or the length of its banking relationship with the \\ lender is short. This evidence indicates that accrual accounting can benefit small business borrowers, but \\ that the information contained in third-party credit scores and obtained through ongoing banking \\ relationships can substitute for the incremental information provided by accrual accounting.
}

\section{Keywords}

accounting sophistication, accrual accounting, credit scores, cost of capital, relationship lending

Disciplines

Accounting | Economics 


\title{
Alternative Information Sources and Information Asymmetry Reduction: Evidence from Small Business Debt
}

\author{
Gavin Cassar \\ The Wharton School \\ University of Pennsylvania \\ Christopher D. Ittner \\ The Wharton School \\ University of Pennsylvania \\ Ken S. Cavalluzzo \\ Wisconsin Capital Management \\ Madison WI
}

November 2010

\begin{abstract}
We examine whether more sophisticated accounting methods (in the form of accrual accounting) interacts with other information sources and the pledging of collateral to reduce information asymmetries between small business borrowers and lenders, thereby lowering borrowers' probability of loan denial and cost of debt. We find that higher third party credit scores, but not the use of accrual accounting, decrease the likelihood of loan denial. However, firms using accrual accounting exhibit statistically lower interest rates after controlling for many factors associated with the cost of debt. Further, third-party credit scores and information obtained through ongoing banking relationships appear to substitute for the incremental information from accrual accounting, with the benefits from accruals decreasing in the firm's credit score and relationship length. We find little evidence that any of the alternative information sources influence loan decisions when collateral is pledged, consistent with theories that collateral provides an alternative means for addressing information asymmetry problems. Finally, our results indicate that borrower characteristics such as the firm's age and legal liability further moderate the relations between the various information sources and interest rates.
\end{abstract}

Keywords: accounting sophistication; accrual accounting; credit denial; credit scores; cost of capital; interest rates; relationship lending; small business; soft information; collateral.

Data Availability: The data used in this study are publicly available from the Federal Reserve Board.

Corresponding author: Gavin Cassar, The Wharton School, University of Pennsylvania, Steinberg Hall-Dietrich Hall (Suite 1300), 3620 Locust Walk, Philadelphia, PA 19104-6365. cassar@wharton.upenn.edu (215) 898 2023. The authors thank Jennifer Blouin, Jeffrey Doyle, and seminar participants at Baruch College, University of Colorado at Boulder, Duke/UNC Fall Camp, EAA Annual Congress, Ghent University, Lancaster University, New York University Summer Camp, University of Pennsylvania, Tilburg University, and Utah Winter Accounting Conference for their comments. The financial support of The Wharton School and Ernst \& Young is greatly appreciated. 


\section{Alternative Information Sources and Information Asymmetry Reduction: Evidence from Small Business Debt}

\section{INTRODUCTION}

A substantial body of accounting research examines the influence of "higher quality" or “more sophisticated” accounting information on a firm's cost of debt capital (see Armstrong et al., 2010 for a review). In theory, borrowers can reduce information asymmetries with lenders by providing higher quality accounting information prepared using more sophisticated methods, thereby increasing access to debt financing and lowering interest rates. Although existing studies provide some support for this proposition, they typically ignore the role played by alternative information sources that may alter or reduce the ability of more sophisticated accounting methods to convey useful and relevant information, leading Beyer et al. (2010, p. 116) to conclude "that one of the biggest challenges and opportunities facing researchers is considering the interactions among the various information sources.”

We begin to address this challenge by examining the influence of alternative information sources and their interactions on small business lending decisions. Lenders are the primary external users of financial reports from small, privately-held firms (Nair and Rittenberg, 1983). When submitting loan applications, potential borrowers must provide some form of financial information, which can vary in sophistication from simple bank statements and tax returns to more sophisticated accounting statements prepared using generally-accepted accounting principles. However, accounting reports are not the only source of "hard" information lenders can use to assess loan applications. ${ }^{1} \quad$ Small business credit scores prepared by third parties offer another method for obtaining hard, quantified information on borrowers (Petersen, 2004), potentially reducing any

\footnotetext{
${ }^{1}$ Petersen (2004) defines hard information as being "quantitative, easy to store and transmit in impersonal ways, and its content is independent of the collection process.” In contrast, soft information is "not easily or accurately reducible to a numerical score, and cannot be communicate this information to the broader lending markets and thus negotiate a lower loan rate from its bank” (Petersen and Rajan, 1994).
} 
informational advantages from more such accounting reports. Credit scoring agencies gather data on credit payment history, business demographics, other public information such as liens, judgments, and bankruptcy proceeding, and (in some cases) financial information to assess the probability that borrowers will meet their loan obligations, giving lenders an alternative method for evaluating loan applications and monitoring borrowers (Petersen and Rajan, 2002; Berger and Frame, 2007). Even more important may be the "softer," more subtle information obtained through a lender's existing relationship with a borrower. Theoretical and empirical studies suggest that relationship banking information may be a better source of information about small business credit worthiness than "hard," quantitative information such as accounting reports or credit scores (e.g., Greenbaum et al., 1989; Sharpe, 1990; Diamond, 1991; Petersen and Rajan, 1994; Cowen and Cowen, 2006), potentially subsuming any incremental information provided by more sophisticated accounting reports. Yet, despite the availability of these various hard and soft information sources, evidence on the extent to which the alternative sources act as complements or substitutes in reducing information asymmetries in small (or large) business lending decisions is limited.

We investigate the interactive effects of accounting information, credit scores, and relationship banking on the availability and cost of debt using a sample of small, privately-held U.S. companies with fewer than 500 employees, gathered in the Survey of Small Business Finance (SSBF) conducted by the U.S. Federal Reserve. Our proxy for accounting sophistication is the use of accrual accounting, one of the most fundamental properties of generally-accepted accounting principles. Unlike larger firms, the small businesses in our sample have no tax or external reporting requirements to use accrual accounting, making its use a voluntary choice. More sophisticated accrual accounting methods are argued to provide incremental information above cash-based accounts, thereby offering a better indicator of company performance and financial standing, and reducing information asymmetries between borrowers and lenders. These claims suggest that lenders will be more likely to 
provide loans and offer lower interest rates to firms using accrual accounting. However, if third party credit scores and/or relationship banking provide complementary or substitute means for reducing information asymmetries, any potential benefits from accrual accounting may be moderated by the information provided by these alternative sources.

In addition to using alternative information sources to address information asymmetry problems, lenders can adjust contractual characteristics (Armstrong et al., 2010). In the small business setting, the primary debt contract characteristic used to address information asymmetries is the provision of collateral by borrowers (Berger and Udell, 2006). Economic theories argue that collateral can serve as an alternative to higher quality information for reducing information asymmetry problems between small business borrowers and lenders (Coco, 2000). These claims suggest that any loan advantages from higher quality accounting (or other) information will be minimized when the borrower has pledged collateral.

We find little evidence that accrual accounting reduces the likelihood of loan denial after controlling for other factors previously found to be associated with small business loan decisions. These (and our other) results are robust to controlling for self-selection in the decision to apply for a loan and endogeneity in the choice to use accrual accounting. However, higher credit scores are negatively associated with loan denial, suggesting that the broad third-party information contained in these scores is used in the initial decision to accept or deny the application, while the incremental information from accrual accounting has little influence on this decision. This evidence is consistent with experimental and qualitative studies finding that the initial approval decision is based on simple, aggregate financial information and other general background data (such as that contained in credit scores) rather than on the analysis of detailed accounting information (Danos et al., 1989; Berry et al., 1993), as well as with banks' increasing use of automated loan approval models based on credit scores (Petersen, 2004). 
In contrast, accrual accounting is negatively associated with the initial interest rate on approved loans, consistent with this more sophisticated accounting method reducing information asymmetries between lenders and borrowers. However, the interest rate benefits from accrual accounting decrease when the borrower's credit score is higher and/or the length of its banking relationship with the lender is longer. That is, firms with lower (higher) credit scores and/or shorter (longer) banking relationships receive greater (smaller) interest rate benefits from accrual accounting. Further analysis indicates that accrual accounting only has a significant influence on interest rates in firms with extremely low credit scores and very short banking relationships. Similar substitution effects are found for credit scores and relationship lengths. For example, any interest rate benefits from higher credit scores appear to be limited to businesses without longstanding relationships with their lenders, and vice versa.

This evidence supports claims that the information obtained in extended banking relationships supersedes other sources of information for small business lending decisions. Similarly, firms with easily obtainable third-party credit scores that are sufficiently high receive little benefit from more sophisticated accrual accounting methods. Supplemental tests provide no evidence that the preparation of financial statements (defined as an income statement and a balance sheet) or the provision of audited financial statements influence lending decisions in our sample, regardless of the use or nonuse of accrual accounting, credit scores, or relationship length. Further analysis indicates that any benefits from these alternative information sources is minimized by the pledging of collateral, consistent with theories that debt contract characteristics can substitute for more informative hard and soft information. Finally, we find that other firm characteristics such as the firm's age and legal liability also moderate the relations between the various information sources and interest rates. Overall, our results suggest that requiring small, private businesses to prepare financial statements using more sophisticated accounting methods is likely to benefit only a subset of 
borrowers and lenders. More importantly, our tests point out the importance of considering the interactions between various information sources and contractual characteristics when assessing the benefits from different accounting practices.

This study makes three related contributions to the accounting literature. First, we extend the limited but growing body of research on small, privately-held businesses, a major sector of the economy. ${ }^{2}$ Accounting standard-setters are placing increasing emphasis on accounting methods in these firms. The American Institute of Certified Public Accountants and Financial Accounting Standards Board (AICPA/FASB, 2006), for example, have established a joint committee to investigate accounting standards in private businesses, most of which are small. Similarly, the International Accounting Standards Board (IASB, 2007) has proposed new accounting standards for small- and medium-sized entities. In addressing these issues, both the AICPA/FASB committee and IASB state that they will consider the benefits to external accounting statement users. Recent accounting studies suggest that more sophisticated audited or accruals-based financial statements can lower the cost of small, private business debt, but do not examine firms using cash accounting (Kim et al., 2007; Minnis, 2010) or firms using accrual accounting but not having financial statements (Allee and Yohn, 2009). None of these studies investigates the influence of alternative information sources, the focus of this study. Similarly, a number of banking studies have examined the impact of banking relationships (e.g., Berger and Udell, 1995; Petersen and Rajan, 1994; Petersen, 2004) or credit scores (e.g., Frame et al., 2001; Berger et al., 2005; Berger and Frame, 2007) on small business lending, but have ignored the role of accounting information. By examining the joint influence of these alternative information sources on small business lending decisions, we provide evidence on the informational settings in which more sophisticated accounting methods (in our case the use of accruals) are likely to provide the greatest benefit to small business borrowers and lenders.

\footnotetext{
${ }^{2}$ See Botosan et al. (2006) and IFA (2006) for reviews of studies on financial accounting practices in small businesses.
} 
Second, we extend research on the broader question of the relative informativeness of more sophisticated or "higher quality" accounting by investigating a setting where accounting sophistication varies substantially and information asymmetries are relatively large. Like large, public companies, the information environment in small businesses includes accounting information, voluntary disclosures of other "hard" and "soft" information, and information produced by third-party intermediaries. However, the small firm setting has the advantage of having fewer competing information sources and no mandatory accounting practices that may affect observed associations between accounting sophistication and lending decisions. In addition, because accrual accounting is a voluntary choice in our sample, we can examine the benefits from more sophisticated accrual accounting using a direct measure of the underlying accounting technology employed by the firm rather than an earnings-based "accruals quality" proxy that is prone to measurement error (Beyer et al., 2010; Dechow et al., 2010). As a result, our small business sample offers cleaner tests of the influence of and interactions between alternative information sources on the cost of debt than is possible using data from large, public companies.

Third, we respond to calls in the accounting and banking literatures to examine the interactions between alternative information choices and debt contract characteristics (e.g., Armstrong et al., 2010; Steijvers and Voordeckers, 2009). Our evidence indicates that lenders attempt to reduce information asymmetry problems either through the information provided by alternative information sources or through collateral requirements. These results indicate that future studies must consider broader information and contractual environments when assessing the implications of accounting practices.

The remainder of this paper is organized as follows. The next section reviews related literature and develops our research questions. Section 3 outlines our research design. Empirical results are presented in section 4 . Section 5 concludes. 


\section{LITERATURE REVIEW AND RESEARCH QUESTIONS}

\subsection{Information Asymmetries and Small Business Lending Decisions}

Lenders base loan approval and pricing decisions on the assessed probability of applicants’ ability to repay loans. However, information asymmetries between firm managers and lenders generally result in insiders having better information on the firm's past and future economic performance and, consequently, on firm default risk (Sengupta, 1998; Bharath et al., 2008). Information asymmetries tend to be greater in small, private businesses, which often have little institutional history and are not required to publicly disclose company-specific information (Butler et al., 2007). As a result, these businesses tend to be more informationally opaque than larger, publiclylisted firms, increasing information risk and potentially influencing lending decisions.

Berger and Udall (2006) argue that financial institutions use four primary methods to compensate for information asymmetries in small business lending decisions: (1) accounting-based lending; (2) credit scoring; (3) relationship lending; and (4) collateral-based lending. ${ }^{3}$ The following sections discuss these methods and their potential interactions in small business lending decisions.

\subsection{Accounting-Based Lending}

One way for small businesses to reduce information asymmetries is providing more informative financial reports. Lenders require small businesses to submit at least some financial information, such as tax returns or financial statements, with their loan applications. This information can be prepared using cash or accrual accounting. ${ }^{4}$

Much of the accounting literature assumes that accrual accounting is more informative than cash accounting, and surveys find that small business lenders rate accrual accounting their preferred

\footnotetext{
${ }^{3}$ Two additional small business lending methods identified by Berger and Udell (2006) are factoring of accounts receivable and leasing. These methods are not included in our study.

4 As discussed in more detail later, small, private businesses in the U.S. are not required to use accrual accounting for securities regulation purposes, and generally do not need to use accrual accounting for tax purposes unless their sales exceed \$5 million. In other countries, small, private firms may be legally required to use accrual accounting for financial reporting or tax purposes (IFA, 2006).
} 
source of financial information for decision-making (Baker and Cunningham, 1993; AICPA, 2004). Since economic transactions are often separate and distinct from their associated cash flows, accrual accounting allows firms to overcome timing and matching problems that make cash accounting a noisy measure of performance (Riahi-Belkaoui, 1992; Dechow, 1994). Through the use of accruals, non-cash economic transactions can be reflected in financial reports in a more timely manner that better matches revenues and costs, thereby providing a better indication of enterprise performance (FASB, 1978). The use of accrual accounting may also provide a positive signal of firm management since this method is typically assumed to reflect greater management sophistication and higher accounting quality, and management may use accruals to signal private information (e.g., Louis and Robinson, 2005). If these potential benefits reduce information asymmetries between applicants and lenders and signal greater credit worthiness, loan denials and interest rates should be lower in small businesses using accrual accounting.

In contrast, some argue that cash accounting provides more informative information on small business applicants' ability to meet their loan obligations, which is the primary financial question facing lenders. For information beyond cash flows to be incorporated into accounting reports, management requires discretion to determine accruals levels. While discretion can be used by management to reflect private information and non-cash economic transactions, management can also use this discretion to distort the reported financial performance and position of the firm for selfinterested purposes. Consistent with lenders recognizing the possibility that borrowers may manipulate accruals to improve reported financial standing, survey evidence from loan officers and financial analysts suggests that the objective nature of cash relative to accruals is an important benefit for lending decisions (Jones, 1998; Jones and Widjaja, 1998). If the net effect of managerial discretion in determining accruals is providing less informative accounting information, then accrual accounting should not be associated with greater loan acceptance or lower interest rates. 
Accounting reports based on cash flows may also provide sufficient information to evaluate solvency and the probability of default, without any of the incremental information provided by accruals. Jones et al. (1995) and Lee (1993) summarize a number of arguments for why cash accounting may be at least as beneficial as accrual accounting for lending decisions. In addition to the arbitrary nature of accruals, these arguments include cash accounting being more predictive of future cash flows and financial distress in many businesses; providing a relatively unambiguous measure of managerial performance; and emphasizing the primary importance of cash resources for ongoing liquidity and solvency. An AICPA (2004) survey supports the notion that cash accounting may be sufficient for many small business lending decisions, finding that 57.7 percent of lenders do not require accrual accounting from private borrowers.

Although considerable debate exists over the relative benefits of cash and accrual accounting for small business lending decisions, empirical evidence is limited. Francis et al. (2005) and Bharath et al. (2008) examine the implications of accruals "quality" for debt contracting in large, public companies. They find lower costs of debt when accruals quality is higher. However, since their sample firms are required to use accrual accounting, these analyses shed no light on the relative benefits of cash and accrual accounting. ${ }^{5}$

Experimental studies have examined the relative importance of these two accounting methods for lending decisions, with mixed results. Riahi-Belakaoui (1992) finds that loan officers examining cash- or accrual-based financial statements from the same company show a clear preference for accrual accounting when determining the firm's ability to repay its loans, loan acceptance, and interest rate. Sharma and Iselin's (2003) experiment, on the other hand, indicates that bankers'

\footnotetext{
${ }^{5}$ Other evidence from listed firms, which are required to use accrual accounting, suggests that analysts find cash flows more important in assessing firm value among highly levered firms, and that analysts are more likely to disseminate cash flow forecasts when the firm is in poor financial health (DeFond and Hung 2003; Previts et al., 1994), both of which may be true of many small businesses. In addition, Hanlon et al. (2006) find that changes in tax laws that required large firms to use accrual accounting for tax purposes caused the informativeness of the accrual-based external financial statements to decline in firms that previously used cash accounting for tax purposes.
} 
judgments regarding solvency are more accurate using cash flow information than using accrual accounting. Jones' (1998) experiment concludes that cash flow statements, compared to accrualbased financial statements, have comparable or greater decision-making influence across a broad variety of lending decisions.

In a related study using the 2003 SSBF data, Allee and Yohn (2009) examine the determinants and lending consequences of financial statement preparation in small businesses. As part of this analysis, Allee and Yohn incorporate a single indicator variable measuring whether firms that report using financial statements (defined as the use of a balance sheet and income statement) to answer the SSBF survey questions and using accrual accounting have lower probability of loan denial and lower interest rates. They find mixed support for these predictions. However, their sample includes firms with sales greater than $\$ 5$ million (which generally are required to use accrual accounting for tax purposes and therefore did not make the voluntary choice to use accruals) and excludes firms that use accrual accounting but did not use financial statements when responding to the survey. In fact, 26.1 percent of the firms in our loan application sample report using accrual accounting but not using financial statements when responding to the survey, and only 10.2 percent report using accruals and financial statements. Thus, Allee and Yohn's study provides only a partial analysis of the influence of accrual accounting on small business lending decisions.

\subsection{Credit Scores And Lending Decisions}

Accounting reports are not the only source of information lenders can use to evaluate the financial condition and riskiness of potential borrowers. Credit scores are now readily available for many small businesses. These scores, which can be purchased from credit rating agencies such as

Dun \& Bradstreet and Experian, incorporate a broad set of information on past credit history, business demographics, other public information on financial history, and (in some cases) firm accounting information (typically provided by the small business itself and not required to be 
prepared using accrual accounting). For example, Dun \& Bradstreet credit scores (which are the most widely-used small business credit scores and the scores used in our analyses) are primarily based on the owners' and firm’s credit payment history, along with information from public filings (e.g., bankruptcy proceedings, judgments, and suits), and (when provided by the firm) financial information on sales, net worth, and working capital (Kallberg and Udell, 2003). Firms are not required to submit financial data to Dun \& Bradstreet, and when they do it typically includes only balance sheet information. For competitive reasons, very few firms submit income statement data to credit rating agencies, so this information generally is not incorporated into their credit scores. Kallberg and Udell (2003) find that information in Dun \& Bradstreet credit scores (particularly credit payment history) exhibits significant incremental ability to predict small business failure, over and above accounting information.

The economics literature on small business lending suggests that the "hard," quantitative information in credit scores provides a cost effective method for lenders to evaluate loan applications and monitor borrowers (e.g., Frame et al., 2001; Akhavein et al., 2005; Berger et al., 2005; Berger and Frame, 2007). Broader availability of third-party credit scores and reduced cost of information transfer have led an increasing number of banks to utilize these scores in loan approval and riskbased pricing models (Cowen and Cowen, 2006; Petersen, 2004), either using the scores by themselves or in conjunction with other information. ${ }^{6}$ Cowen and Cowen's (2006) survey of banks' use of credit scores supports the claimed advantages from this information source, with the highest ranked reason for adopting credit scoring being quantifying credit evaluation, followed by simplifying loan applications and inexpensive access to additional information. On the other hand, neither credit scores nor accruals may have a significant effect on lending decisions. Banks rank cash flow information the most important factor in small business loan approval decisions, far above credit

\footnotetext{
${ }^{6}$ Lenders can develop their own credit scores instead of using scores from third-party vendors. However, 78.6 percent of banks surveyed by Cowen and Cowen (2006) use small business credit scores purchased from third-parties.
} 
scores (Cowen and Cowen, 2006), suggesting that cash accounting information may be sufficient for lending decisions.

\subsection{Relationship Lending}

The discussion thus far has focused on the influence of "hard" information on lending decisions. While the hard information in accounting reports and credit scores may be important factors in small business lending decisions, even more important may be the "soft" information obtained through ongoing banking relationships (Berger and Udell, 1995; Petersen and Rajan, 1994; Petersen, 2004). This information, such as a loan officer's knowledge of the potential borrower's ability, character, and trustworthiness, is "soft" in the sense that it is hard to quantify and communicate to others, and may not be verifiable by outsiders. If the accuracy of information regarding a potential borrower increases the longer the relationship between the parties exists, and thereby reduces information asymmetries, past dealings with a borrower may provide superior information for assessing credit worthiness (Diamond, 1991; Petersen and Rajan, 1994).

Despite the potential informational advantages from ongoing banking relationships, their theoretical influence on lending decisions is unclear. Boot and Thakor (1994) show that interest rates decline as the savings from the bank's improved knowledge of the borrower is passed on to the borrower. In contrast, Greenbaum et al. (1989) and Sharpe (1990) predict that interest rates increase with relationship length as the bank's improved knowledge may "lock in" the borrower in the relationship. The conflicting theoretical predictions are mirrored in the mixed empirical evidence on the impact of relationship duration on interest rates (e.g., Ongena and Smith, 2001; Petersen and Rajan, 1994, 1995; Berger and Udell, 1995; Cole, 1998; Bharath et al., 2009). Thus, the influence of banking relationships on loan decisions remains unclear, particularly in the presence of other information sources.

\subsection{Interactions Among Alternative Information Sources}


While each of the above information sources is part of the firm's “information environment," little empirical research has been devoted to the interdependencies and complementarities between accounting and other information sources (Beyer et al., 2010). For example, whether firm-produced accounting information, third-party credit scores, and soft information from on-going banking relationships are complementary or substitute information sources is unclear. Berger and Udell (2006) argue that banks can use combinations of these information sources to minimize information asymmetry problems. Similarly, Cowen and Cowen (2006) suggest that banks can supplement thirdparty credit scores with additional information such as financial reports based on accrual accounting, with the combined information sources acting as complements and further reducing information asymmetries. Other studies, however, suggest that these alternative information sources are substitutes. Bharath et al. (2009), for example, find that the benefits from relationship lending are nullified if the firm has publicly-rated debt. Brown and Zehnder’s (2007) experiment shows credit scores have little effect on lending decisions in settings with repeated interactions between borrowers and lenders. Cowen and Cowen's (2006) survey finds that respondents rank banking relationships as the dominant factor in small business lending decisions, despite the availability of accounting information and credit scores

The mixed empirical results for the three individual information sources, together with the availability of alternative information sources, has led to calls for researchers to examine the interactions among these sources when assessing their impact on lending decisions (Armstrong et al., 2010; Byers et al., 2010; Steijvers and Voordeckers, 2009). These calls lead to our first research question:

To what extent do accrual accounting, credit scores, and relationship banking interact to influence small business lending decisions?

\subsection{The Moderating Effects of Collateral}


Rather than relying on information gathering to mitigate information asymmetries with potential borrowers, lenders can modify loan contract features. In the small business lending context, this frequently takes the form of collateral pledging (Berger and Udell, 2006; Steijvers and Voordeckers, 2009). Economic theories contend that collateral can reduce information asymmetry problems through two means (see Coco, 2000, for a review). First, pledging collateral can reduce adverse selection problems by serving as a screening mechanism, with higher quality borrowers more willing to put their assets at stake. Second, collateral can play an incentive role by increasing the borrower's effort and minimizing the probability that the borrower will shift from low-risk to higherrisk projects, thereby reducing moral hazard problems. However, despite these potential benefits, empirical evidence on the value of collateral as an information asymmetry reducing tool is inconsistent. Steijvers and Voordeckers' (2009) review concludes that a plausible explanation for the mixed results, and a major limitation of this literature, is examining the use of collateral in isolation of other information asymmetry reducing mechanism such as hard and soft information sources. This conclusion is reinforced by Bharath et al.'s (2008) finding that the use of collateral is more frequent when accruals "quality” is lower. The potential tradeoffs between the alternative information sources and loan contract features leads to our second research question:

To what extent does the pledging of collateral substitute for higher quality information sources in small business lending decisions?

These open empirical questions are of significant importance since firms have the discretion to invest in greater accounting sophistication and, with sufficient time, to transact with lenders to reduce information asymmetries, potentially leading to greater access to capital and lower cost of debt. However, if these benefits are only obtained under certain conditions, such as settings where alternative information sources or contractual features do not adequately minimize information 
asymmetry problems, then mandatory or across-the-board promotion of greater accounting

sophistication to improve small business access to capital may not be appropriate.

\section{RESEARCH DESIGN}

\section{Sample}

We examine the implications of interactions between accrual accounting and alternative information sources on small business debt using data from the 2003 Survey of Small Business Finance (SSBF) administrated by the U.S. Federal Reserve and Small Business Administration. The 2003 SSBF is a nationally representative sample of 4,240 non-farm, non-subsidiary business enterprises with fewer than 500 employees. A stratified random sampling procedure based on employment size, urban/rural status, and census divisions (as reported in Dun’s Market Identifier file) was employed. The survey used a two-stage collection process. First, an initial interview assessed firm eligibility for the SSBF using the preceding criteria. Second, a main telephone interview of eligible establishments was conducted, with an average duration of 59 minutes. The overall response rate was 32 percent (FRB, 2006).

We remove publicly-held entities $(\mathrm{n}=5)$ and those with missing or non-positive assets, sales, or shareholders $(n=508)$. We also remove 351 corporations that were not S-corporations or were partnerships with annual gross receipts above \$5 million since these entities are prohibited from using cash accounting for tax purposes (IRS, 1999). ${ }^{7}$ We eliminate these observations to focus on firms that have no regulatory requirement to use accrual accounting for any purpose. As a result, the

\footnotetext{
${ }^{7}$ Later versions of IRS Publication 538 were released in March 2004, January 2007, and March 2008, but the 1999 version was the most current at the time of the 2003 SSBF. Additional regulatory triggers related to inventory, corporate form, and operations may also require accrual accounting. However, several regulatory exemptions override these triggers. Rev. Proc. 2001-10 and Rev. Proc. 2002-28 provide detailed exemptions for entities with gross annual receipts under \$1 million and \$10 million, respectively. In unreported results, we repeated the analyses using firms with gross annual receipts under \$1 million or under \$10 million. The findings are consistent with those reported. However, the interest rate findings for accrual accounting are slightly stronger in magnitude when gross receipts are under $\$ 1$ million. In addition to tax requirements, the Securities and Exchange Commission mandates the use of accrual accounting for: 1) all listed firms; 2) firms that previously offered shares under the Securities Exchange Act of 1934 with greater than 300 shareholders in the class of offered securities; or 3) firms with \$10 million in assets and 500 shareholders. Our sample does not meet any of these conditions.
} 
sample reflects firms that voluntarily chose to use cash or accrual accounting. We also remove 83 entities that did not have a credit score or did not respond to the accrual accounting question.

We further restrict the sample to firms that recently applied for a loan, provided the outcome of the application, and provided responses to survey questions on the factors predicted to be associated with loan denial. These criteria reduce the sample to 1,385. Finally, in tests examining interest rate determinants, we restrict the sample to the subset of firms with recent debt financing that provided the interest rate on their most recent loan and had no missing responses to the questions used for our independent variables. These criteria reduce the number of firms in our interest rate analyses to 1,191 .

Table 1 summarizes the sample selection process for the study, and Table 2 provides descriptive statistics for the dependent and independent variables used in our analyses. The mean (median) firm has assets of $\$ 1,581,371(\$ 144,544)$, with 92 percent managed by an owner of the firm and 85 percent family owned.

\subsection{Variables}

3.2.1. Availability and Cost of Debt. Respondents applying for at least one loan in the previous three years were asked whether their loan applications were approved. Consistent with previous research, we assess the availability of debt using the variable Loan denial, which equals one if the entity was denied credit on any loan requests during this period, and zero otherwise. Eleven percent of the firms that applied for loans were denied in the previous three years. We measure the cost of debt using the variable Interest rate, which is the original interest rate on the most recently approved loan or line of credit. ${ }^{8}$ The mean (median) initial interest rate is 5.97 percent (5.90 percent) on a mean (median) loan amount of $\$ 862,542(\$ 100,000){ }^{9}$

\footnotetext{
${ }^{8}$ The direct measurement of loan interest rates rather than the use of an estimated average cost of debt measure inferred from the income statement and balance sheet avoids measurement concerns such as identifying liabilities that are contracted at arm's length and staleness caused by loan maturities greater than one year. These concerns are exacerbated
} 
3.2.2. Accrual Accounting Use. Our accrual accounting indicator is obtained from the question: "Did the business use cash or accrual accounting to prepare its financial records for the fiscal year ending [DATE]?” The survey defined cash and accrual accounting as follows:

The distinction between the cash basis of accounting and the accrual basis of accounting lies in the time at which revenues and expenses are recognized. Under cash basis accounting, revenue is recorded when payment is collected from the customer, rather than when a sale is actually made. Under accrual basis accounting, however, revenue is recorded at the time of the sale even if cash has not yet been collected.

Similarly, expenses are recorded under cash basis when payment is made, rather than when related goods or services are used. Expenses are recognized when the related goods or services are used, rather than when payment is made, under the accrual basis of accounting.

For example, for a business with a fiscal year ending December $31^{\text {st }}$, interest incurred for the month of December will be recorded as an expense under the accrual basis of accounting, even if payment is not made until the following year. Under the cash basis, however, interest incurred but not paid is not recognized as an expense.

If respondents were uncertain about their use of cash or accrual accounting, they were referred to the relevant box in their tax returns requiring them to indicate whether they used cash or accrual accounting when completing their tax forms. Thirty-six percent of our sample reported using accrual accounting. The variable Accrual equals one if the firm used accrual accounting, and zero otherwise. Importantly, this measure of accounting sophistication is not based on the empirical properties of accounting numbers, but on the underlying technology for computing and reporting financial information to the firm's financers, thereby avoiding concerns that it is capturing firm or industry characteristics that can cause common earnings-based accruals proxies to erroneously exhibit greater accounting “quality” in some situations (Beyer et al., 2010; Dechow et al., 2010).

when examining smaller, private firms (Cassar, 2010) and can result in significant noise in an inferred cost of debt measure.

${ }^{9}$ A minority of studies that have investigated the association between the cost of debt and accounting quality and sophistication have specified the cost of debt variable as the difference between the interest rate on the loan and the prime rate (e.g., Blackwell, Noland, and Winters, 1998). To examine whether our findings are robust to this specification, we adopt this alternative cost of debt variable and remove prime rate as a control variable from our interest rate model. In unreported results, all findings are consistent using this alternative cost of debt measure. 
3.2.3. Credit Scores. The Federal Reserve Board purchased credit scores for the respondents' businesses from Dun \& Bradstreet. Like most third-party credit scoring methods, the Dun \& Bradstreet small business commercial credit scores are based on information regarding the firm's historical and current payment behavior, other publicly-available data that may influence loan payment delinquency (e.g., liens or open lawsuits), business demographics, and (when provided by the potential borrower) financial strength and performance. The scores range from 0 (highest risk) to 100 (lowest risk). In our sample, the mean (median) Credit score is 58.97 (63.00).

3.2.4. Relationship Banking. We assess the influence of relationship banking on interest rates using the variable Relationship, which equals the log of the number of years the firm had conducted business with the lending institution at the time of the most recently approved loan application plus one. $^{10}$ Following prior studies (e.g., Petersen and Rajan, 1994), we assume that information asymmetries are lower when the firm has conducted business with the lending institution for a longer period of time. The number of years the firm has conducted business with the lending institution ranges from 0 to 79 years $($ mean $=8.85$; median $=5.50)$.

3.2.5. Control Variables. Several variables are used to control for other potential determinants of loan denial and interest rates. ${ }^{11}$ These variables are drawn from earlier research on small business lending (e.g., Cavalluzzo et al., 2002; Petersen and Rajan, 1994, 2002; Allee and Yohn, 2009). Control variables from the SSBF include firm leverage, size, use of collateral, and loan characteristics such as loan type (e.g., line of credit, capital lease, vehicle loan), amount, and whether the loan's

${ }^{10}$ The survey does not provide information on the length of banking relationships for denied loans. As a result, we are unable to examine the effect of relationship length on the availability of debt.

${ }^{11}$ Several of the independent control variables used in our tests are financial ratios based on accounting values. The use of these ratios is consistent with previous SSBF-based research. However, the accounting values may be a function of the firm's accounting methods, potentially altering the financial ratios in a systematic manner (Guenther, Maydew, and Nutter, 1997). To address this potential limitation, we replaced all measures based on total assets (such as the log of total assets and cash-to-assets) with measures based on the number of employees. Further, we removed financial ratios that rely on accounting profits. All of the study's inferences remain after reducing reliance on accounting values for our independent variables. 
interest rate is fixed or floating. These data are supplemented with information from Federal Reserve Reports, namely: 1) Prime rate, which equals the prime rate at the start of the loan; 2) Duration spread, defined as the difference between a Baa bond and yield on 10-year treasury bonds at the time of the loan; and 3) Term premium, which equals the difference between the yield on a government bond with similar maturity and the yield on a treasury bill at the start of the loan. If the loan does not have a fixed maturity, the term premium equals zero. ${ }^{12}$

\subsection{Correlations}

Table 3 provides correlations between variables measuring the expected determinants of loan denial in Panel A and interest rates in Panel B. Most or all of the control variables are significantly correlated with the two loan variables, and their signs are consistent with previous research. Accrual has a small but significant correlation $(p<0.05)$ with Credit score, and a significant, negative correlation with loan denial and interest rates $(p<0.01)$. Relationship is negatively correlated with interest rates $(p<0.01)$ and positively correlated with Credit score $(p<0.01)$, but is not significantly associated with Accrual.

\section{RESULTS}

\subsection{Econometric Issues}

12 The selection of control variables was based on their observed effect on loan denial and interest rate reported by research using previous SSBF survey data. We also estimated our models using a large number of other control variables. In the loan denial models, these included the log of employment, owners' education, owners' years of experience, whether the firm was owner-managed, indicators for the owners' gender and race, sales scope, distance between borrower and lender, banking concentration, and corporate form. We estimated the interest rate models after including additional variables for region, year, log of employment, rural location, education, years experience, whether the firm is owner-managed, log of firm age, sales scope, whether the firm has a checking (savings) account with the lender, type of financial institution, if the firm was previously denied a loan, length of relationship and distance from lender, whether a guarantee was used, type of collateral, inverse of loan maturity, loan fees, percentage to close loan, sales growth, asset turnover, profit margin, return on assets, firm and owner bankruptcy and judgment, banking concentration, and corporate form. Since the results vary little using these additional control variables, and their inclusion substantially reduces sample sizes in our tests due to missing data, they are not included in the reported models to simplify presentation. 
Two important econometric issues in our study are the endogenous choice of accounting sophistication and the self-selection of firms that decide to apply for a loan.

4.1.1. Endogeneity. The level of accounting sophistication is a choice variable for the firm. Endogeneity in this choice is an important issue because many factors that influence this decision are also likely to influence lending decisions, potentially leading to correlated omitted variables problems. We therefore supplement our accrual accounting variable with a variable that attempts to control for endogeneity issues.

Addressing endogeneity requires instrumental variables that are correlated with the use of accrual accounting but are uncorrelated with errors in the loan denial or interest rate models. We use two variables to instrument accrual accounting use: 1) the presence of accounts receivable (coded one if credit is provided to customers and zero otherwise), and 2) industry days in inventory (defined as the average days of inventory for companies in the firm's two-digit SIC code, as reported in Compustat for firms with less than $\$ 5$ million in revenues). We use an indicator variable for the presence of accounts receivable rather than the value of these accounts to minimize concerns that larger accounts receivable can serve as collateral or be factored, thereby influencing lending decisions. ${ }^{13}$ Industry (rather than firm-specific) inventory levels are used to minimize concerns that individual firms choose inventory levels to influence lending decisions. As the length of time between economic events and their associated cash flows widens, the potential benefits from accrual accounting and its revenue recognition and matching principles should increase (Dechow, 1994). The presence of accounts receivable and increasing days in inventory should therefore lead to greater

13 Slightly fewer than two-thirds (63.9 percent) of firms having accounts receivable use accrual accounting. Thus, the use accrual accounting and the presence of accounts receivable are not synonymous. 
need for the firm to address these timing and matching problems, increasing the benefits from (and the likelihood of accrual accounting use. ${ }^{14}$

Table 4 provides results from probit models examining the exogenous determinants of Accrual. The left-most columns display results using the instruments alone, while the right-most columns display results with the instruments and the other predicted exogenous variables for the denial model (results using interest rate controls not reported to simplify presentation). In both models, the presence of accounts receivable and days in inventory have significant, positive associations with accrual use $(p<0.01$, two-tailed $)$.

Larcker and Rusticus (2010) argue that only under certain conditions will 2SLS provide results superior to OLS. We evaluate these conditions and the validity of our instruments by examining the partial $\mathrm{R}^{2} \mathrm{~s}$ and partial F-statistics of our instruments when included in models with all other exogenous variables. The partial $\mathrm{R}^{2}$ is 0.054 and partial F-statistic is $36.88(p<0.0001)$ for loan denial, while the partial $\mathrm{R}^{2}$ is 0.046 and partial F-statistic is $28.49(p<0.0001)$ for interest rate. In both models, the instruments’ incremental explanatory power is statistically significant and above the recommended magnitudes for adopting our instruments in a 2SLS specification (Stock, Wright, and Yogo, 2002). These results not only support the use of our instrumented accrual accounting variable in subsequent tests, but also provide evidence of the convergent validity of our accounting choice measure.

4.1.2. Self-Selection. Another important econometric issue in the loan denial tests is the fact that only a subset of firms in the survey applied for debt financing. Self-selection may affect statistical inferences because the choice to apply for financing is truncated (i.e., firms that decided not

\footnotetext{
${ }^{14}$ Another potential instrument for the use of accrual accounting is the presence of accounts payable. We do not use this as an instrument because it represents trade credit, a potential indicator of credit worthiness. When we include an indicator for the presence of accounts payable in the accounting method prediction model, it is positive and significant. Results are invariant to using alternative predicted accounting sophistication variables that incorporate accounts payable. All findings utilizing instrumental variables are also invariant to using only the presence of accounts receivable or only industry days in inventory as instruments.
} 
to apply are excluded) and may be correlated with other factors associated with loan acceptance or denial, potentially leading to biased parameter estimates. Heckman (1976) proposes a two-step process to account for selection biases. In the first stage, the self-selection decision is modeled using a dichotomous choice method such as logit or probit. The resulting inverse Mills ratio is then used as an additional explanatory variable in the second-stage model to control for selection biases.

We model the firm's decision to apply for a loan as a function of several variables expected to influence the entity's demand for debt capital. These variables include firm age, firm size (measured using the log of total assets), ownership characteristics (the presence of an owner-manager and the number of owners), cash needs (proxied using the cash-to-assets ratio), profitability (ROA), and growth (sales growth over one and three year periods).

Results from the first-stage probit estimation are presented in Table 5. Firms applying for loans tend to have more assets and owners, to be owner-managed, and to have lower cash-to-asset ratios and stronger sales growth over the past year. We use the first-stage probit estimate to obtain the inverse Mills ratio for the loan application decision, and then include this ratio in the second-stage loan denial estimates to account for self-selection in loan applications (Amemiya, 1985).

\subsection{Determinants Of Loan Acceptance Or Denial}

Our first tests examine the determinants of loan acceptance or denial. Table 6 provides results from these probit models. ${ }^{15}$ Since the dependent variable is an indicator representing whether the

15 The SSBF provides imputed data for most missing values in the original survey, with the imputed data provided in the publicly available datasets in five implicates. In our tests, all imputed data are classified as missing. We re-estimated the models using actual or imputed data for all observations with non-imputed values for the primary dependent variables (accrual accounting, credit score, relationship, loan denial, and interest rate). Results using imputed data are consistent with those reported in the tables, suggesting that missing value biases are not driving our results. Our analyses are also performed using unweighted econometric techniques. However, the SSBF is constructed from a stratified random sample based on firm size, geographic region, and urbanization. Sample weights are provided to allow parameter estimates to be based on the population of firms in the SSBF's sampling frame. We repeated the analyses using weighted least squares based on the sample weights provided in the SSBF. Findings using weighted analyses are consistent with the reported findings, with the primary difference being statistically and economically stronger associations between information sources and interest rates. 
firm was denied debt in the past three years, only those firms that applied for loans are included in these analyses. The primary variables of interest in these tests are the "hard" information provided by accounting reports and the firm's credit score. We also control for factors that previous research suggests are determinants of small business loan acceptance or denial, including firm size and age, profitability, leverage, and previous credit history. The inverse Mills ratio is included to control for self-selection in the decision to apply for a loan.

When we estimate the model using the uninstrumented Accrual measure, the coefficient on this variable is negative but statistically insignificant. In contrast, the coefficient on Credit score is negative and highly significant $(p<0.01$, two-tailed). These results suggest that higher credit scores increase the probability that a small business receives a loan, but that the use of accrual accounting has no effect on this decision.

To examine whether accrual accounting and credit scores are complements or substitutes, we add the interaction between these two variables. For example, the benefits from accrual accounting may be greater for firms with lower credit scores, and vice versa. Alternatively, any benefits from accrual accounting may be higher when this method is combined with high credit scores since the information provided by one source may be used to validate the information provided by the other. Despite these conjectures, the interaction term is not significant, while Credit score remains significant and Accrual remains insignificant.

Results are similar when we replace Accrual with the instrumented use of accrual accounting (denoted Accrual_hat) to control for endogeneity in the choice to use this accounting method. We adjust the standard errors in these tests to account for Accrual_hat being an estimate. The coefficients 
on Credit score continue to be negative and significant ( $p<0.01$, two-tailed), while the coefficients on Accrual_hat and the interaction term are not statistically significant. ${ }^{16}$

Coefficient signs on the control variables are generally consistent with expectations, with firm size and firm age significantly reducing the probability of loan denial, and firm leverage and previous delinquencies significantly increasing loan denial probability. Self-selection in the firms choosing to apply for a loan (Inverse Mills ratio) is a significant predictor of loan denial ( $p<0.01$, two-tailed), indicating that the factors that increase the probability a firm applies for a loan also reduce the likelihood that the loan will be denied.

In sum, we find no evidence that the use of accrual accounting methods influences the probability that a small business's loan is approved or denied. Instead, our results suggest that credit scores, which provide a relatively low-cost method to quickly assess small business repayment probability, are more likely to be used by lenders to make the initial decision to accept or deny a loan application. $^{17}$

\subsection{Interest Rates Determinants}

We next examine the factors influencing the interest rates on small business loans, given the lender's decision to grant the loan. These tests are limited to respondents who received a loan in the past three years and provided the interest rate on the latest loan. Results from these tests are provided in Table 7. The models' $\mathrm{R}^{2}$ s range from 0.185 to 0.191 , similar to or larger than the magnitudes in other small business interest rate studies (e.g., Cavalluzzo et al., 2002; Petersen and Rajan, 1994, 2002; Allee and Yohn, 2009; Kim et al., 2007). The signs on the control variables are generally

${ }^{16}$ Ai and Norton (2003) note that the sign of the coefficient on the interaction term in a dichotomous model need not be the same statistical significance or sign as the marginal effect for each observation. To investigate this concern, we investigate these marginal effects. Using model 2, 68.7 percent of the individual marginal effects are positive, with none statistically significant at the 0.05 level. Using model 4, 53.8 percent of the individual marginal effects are positive, with only two statistically significant at the 0.05 level. Overall, these results corroborate the insignificant associations between the interaction term and loan denial in Table 6.

${ }^{17}$ As noted earlier, the SSBF survey does not provide information on the length of banking relationships when loans were denied. As a result, we are unable to examine the association between relationship length and loan denial. 
consistent with expectations, with leverage and fixed rate loans positively related to interest rates, and loan amount negatively associated with interest rates.

In contrast to the loan denial tests, the coefficients on the uninstrumented Accrual measure are negative and significant. The coefficient on Accrual in the first model suggests that the use of accrual accounting reduces interest rates by 37.3 basis points, which is equivalent to 6.2 percent of the mean interest rate in the sample. ${ }^{18}$ Credit score and Relationship on the other hand, have no significant effects on interest rates in the first model. Models 2, 3, 4 include two-way multiplicative interactions between (1) Accrual and Credit score, (2) Accrual and Relationship, and (3) Credit score and Relationship, respectively, to investigate potential complementarities or substitutions between these alternative information sources. We examine separate two-way interactions and do not include a three-way multiplicative interaction in these tests because the inclusion of higher order multiplicative interactions using the same variables as those used for the main and lower order interaction effects increases a regression model’s susceptibility to multicollinearity problems.

When the interaction between Accrual and Credit score is included as an additional predictor variable, the coefficient on the interaction term is positive and significant and the coefficient on the Credit score main effect is negative and significant. The differing signs on the Accrual and Credit score main effect variables relative to the interaction term imply that these two information sources are substitutes. That is, firms with lower (higher) credit scores receive greater (smaller) interest rate benefits from accrual accounting. For example, the interest rate benefit from accrual accounting for a

${ }^{18}$ In economic terms, the benefit from accrual accounting for the mean (median) loan amount of $\$ 831,262$ $(\$ 100,000)$ in the interest rate sample is $\$ 3,100.61$ (\$373), and the total benefit from accrual accounting for the mean (median) total debt of $\$ 1,938,170$ (\$251,500) is $\$ 7,229.37$ (\$938). It should be noted that the benefits and incentives to use accrual accounting and other more sophisticated accounting methods are not confined to debt contracting. For example, Cassar (2009) argues that firms' accounting sophistication can be driven by many influences including contracting demands within the firm, decision-making and performance evaluation requirements, firm competition and price pressures, and manager's knowledge and experience. Therefore, the choice to use accrual accounting is not solely a function of the benefits obtained from expected changes in a firm's cost of debt. 
firm with a credit score at the $25^{\text {th }}$ percentile is 62 basis points $(-1.004+0.010 \times 38), 37$ basis points at the median credit score, and only 12 basis points at a credit score at the $75^{\text {th }}$ percentile.

Similarly, in Model 4 the interaction between Credit score and Relationship is positive and significant while the coefficient on Relationship is negative and significant, consistent with Credit score and Relationship being substitute information sources. In Model 3, the interaction term between Accrual and Relationship is also positive but is not statistically significant.

Model 5 presents the model with all three interactions included. The maximum VIF for this specification is 9.03, slightly below the threshold of 10 or higher denoting unacceptable multicollinearity (Kennedy 2003). The main and interaction effects are generally consistent with the models including only one interaction at a time. ${ }^{19}$ To provide evidence on the economic significance of the substitution effects, Panel A of Table 8 presents the estimated benefits from using accrual accounting based on the quartile of credit score and relationship length. The estimated benefit of accrual accounting is decreasing in both credit score and relationship length. For example, Panel A indicates that the benefit from accrual accounting for a firm with both a credit score and a relationship length at the $25^{\text {th }}$ percentile is 70.3 basis points $(-1.196+0.010 \times 38+0.245 \times 0.45)$, but only 3.2 basis points when both the credit score and relationship length are at the $75^{\text {th }}$ percentile.

Untabulated results are similar when Accrual_hat is used to control for endogeneity in the use of accrual accounting (with standard errors corrected for this variable being estimated). The coefficients are significantly negative on the Accrual_hat, Credit score, and Relationship main effects $(p<0.10$, two-tailed). Coefficient signs on the interaction terms are consistent with those using Accrual. However, the interactions between the instrumented accrual measure and credit

${ }^{19}$ To examine the potential influence of selection biases on these inferences, we repeated the analyses using the inverse Mills ratios for firms that: 1) recently applied for debt financing; and 2) recently obtained debt financing. Coefficients on both inverse Mills ratios were statistically insignificant, while the coefficients and statistical significance of the accrual accounting, credit score, relationship length, and interaction variables were similar, suggesting that our interest rate results are not driven by selection biases. 
scores and between credit scores and relationship length are marginally insignificant at conventional levels ( $p=0.16$ and 0.11, two-tailed, respectively), and the interaction between Accrual_hat and Relationship is not significant. Panel B of Table 8 shows the estimated economic benefit from (instrumented) accrual accounting for a firm with both a credit score and a relationship length at the $25^{\text {th }}$ percentile is 61 basis points $(-0.815+0.005 \times 38+-0.004 \times 0.45)$, and 34 basis points at a credit score and relationship length at the $75^{\text {th }}$ percentile. These results again suggest that the benefits of accrual accounting on interest rates are lower when the entity's credit score is higher, but no longer provide evidence of a tradeoff between accrual accounting and relationship length on interest rates.

\subsection{Alternative Interaction Specifications}

The preceding interest rate tests assume very specific linear relationships and multiplicative interactions, and only consider the interactions between two of the three information sources at a time. However, the influence of these alternative information sources on interest rates may vary depending upon the quality of the information provided by both of the other sources, and the relations between the individual information sources and their interactions need not have linear multiplicative associations with interest rates.

We conduct two tests to investigate more complex interactions among the three information sources. First, we partition the sample into two groups at the median lending relationship length. ${ }^{20}$ The mean (median) relationship is 2.03 years (1.83 years) in the subsample of shorter relationships, and 15.94 years (13.00 years) in the subsample of longer relationships. We estimate separate regressions of interest rates on Accrual, Credit score, their interaction, and the control variables for each group. As shown in Table 9, we again find significant, positive coefficients $(p<0.10$, twotailed) on the accrual and credit score main effects and a significant, negative coefficient on their

${ }^{20}$ Partitioning our sample, rather than pooling all firms, allows the coefficients on all of the interest rate predictors to vary across short and long banking relationships. In addition, partitioning minimizes the multicollinearity problems that typically occur when a large number of multiplicative interactions are included in a regression model. A disadvantage of partitioning is a potential loss in estimation efficiency. 
interaction term in the subsample of firms with shorter relationship lengths. However, Accrual is not significant in firms with longer lending relationships. This evidence is consistent with claims that the information provided by longer banking relationships subsumes any incremental information provided by more sophisticated accounting information or third-party credit scores. However, when lending relationships are relatively short, both accrual accounting and higher credit scores can serve as (substitute) mechanisms for reducing information asymmetries with lenders. ${ }^{21}$

Second, we replace the Accrual, Credit Score and Relationship variables and their associated interactions with a series of indicator variables that classify firms based on whether they: 1) do or do not use accrual accounting; 2) have a credit score above or below the sample median (63); and 3) have a relationship with the lending institution longer or shorter than the sample median (5.5 years). Panel A of Table 10 reports the number of firms in each combination of accrual accounting, credit score, and relationship length, as well as the results from the regression of interest rates on indicators for these combinations and the control variables. The (omitted) base case in the model is the group of firms that does not use accrual accounting, has relatively low credit scores, and relatively short lending relationships. The statistically significant negative coefficients $(p<0.01)$ on the seven indicator variables imply that the highest interest rates are found in the base case of firms in the no accrual, low credit score, and short relationship category, indicating that information asymmetries are highest in these firms.

To provide evidence on the associations between interest rates and the other firm groupings, Panel B of Table 10 presents Wald tests of the joint statistical significance of Accrual, Credit Score,

${ }^{21}$ We conduct similar analyses after partitioning by credit score (using the sample median) or by accrual use. For each of these specifications, we find statistically negative associations between the two remaining information sources and interest rates for firms with lower credit scores or the non-use of accrual accounting, and no association between relationship length, accrual use, or credit scores in firms with higher credit score or accrual accounting. These results are consistent with the main specifications which suggest that the benefits from accrual use, higher credit scores, and longer relationships are primarily found in firms that are weaker in the other information dimensions. 
and Relationship for the various combinations. Consistent with the earlier specifications, Accrual has an overall significant effect on interest rates $(F=3.59, p=0.0064)$. However, when we subdivide the sample by credit score and relationship length, we only find a significant Accrual effect in firms with credit scores below the sample median $(F=7.10, p=0.0009)$ or relationships shorter than the sample median $(F=6.88, p=0.0011)$. We find no significant accrual effect in firms with higher credit scores or longer relationships. Moreover, when firms are further categorized by the combination of credit score and relationship length, accrual accounting is only significantly associated with interest rates in firms having both low credit scores and short relationships $(F=$ 13.75, $p=0.0002$ ), with accrual accounting estimated to reduce this group of firms' cost of debt by 132 basis points. These results imply that the interest rate benefits from accrual accounting are limited to firms that do not have alternative means for reducing information asymmetries.

The Wald tests for Credit Score and Relationship exhibit similar findings, with the only statistically significant interest rate benefits from these information sources confined to the subgroups of firms that do not use accrual accounting or have relatively low scores on the other information source. Specifically, Credit score has a significant effect in non-accrual, short relationship firms $(F=12.94, p=0.0003)$, and Relationship has a significant effect in non-accrual, low credit score firms ( $F=8.94, p=0.0036$ ). Overall, the evidence from the classification-based specifications implies that firms receive little if any interest rate benefits from improving a given information source if they are already relatively strong in one of the alternative information sources. ${ }^{22}$

\subsection{Alternative Accounting Sophistication Measures}

Accrual accounting is only one indicator of accounting sophistication. Prior small and private business studies indicate that factors such as the preparation of financial statements and audits can

${ }^{22}$ In unreported results, we further subdivided the sample into groups based on accrual use and sample terciles for credit scores and length of relationship, respectively. Results are consistent with those using the classifications reported in the tables, with the alternative information sources only having significant effects on interest rates when the values for the other information sources were lowest. 
also influence loan application outcomes (e.g., Allee and Yohn, 2009, Minnis, 2010; Kim et al., 2007). We therefore compute a second, more comprehensive, accounting sophistication variable to examine the influence of these other accounting system attributes on our results. AccSophistication is the sum of indicators for three accounting practices: (1) accrual rather than cash accounting; (2) the preparation of financial statements (defined as a balance sheet and income statement); and (3) the use of audited financial statements. These indicators represent generally-accepted accounting principles that have been advocated by proponents of improved small business accounting (e.g., AICPA/FASB, 2006; IASB, 2007). The financial statement and audit indicators are based on questions asking whether respondents used financial statements to answer the financial questions in the survey and, if so, whether the financial statements were audited by a professional accountant or accounting firm. ${ }^{23}$ The resulting AccSophistication variable ranges from 0 (no use of accrual accounting, financial statements, or audited financial statements) to 3 (use of all three practices), with a mean (median) score of $0.63(0.00)$.

Untabulated results using AccSophistication (or an instrumented AccSophistication_hat variable) are weaker than those using the accrual measures. In economic terms, the benefit of increasing the AccSophistication (AccSophistication_hat) score by 1 practice is 20 (120) basis points for a firm with both a credit score and relationship length at the $25^{\text {th }}$ percentile, and -7 (66) basis points with a credit score and relationship length at the $75^{\text {th }}$ percentile. When we replace AccSophistication with separate variables for accruals, financial statements, and audits, the financial statement and audit indicators add no statistically significant exploratory power $(p<0.10)$ in any of the reported specifications, while the accrual results remain similar to those reported in the tables.

\footnotetext{
${ }^{23}$ A potential limitation with the financial statement and audit indicators is that using financial statements to answer the survey does not necessarily indicate whether the firm prepares financial statements, since respondents can prepare financial statements but rely on other information (such as tax forms, bank statements, etc.) for their survey responses. If this is true for many respondents, our AccSophistication variable will not fully reflect the use of these more sophisticated accounting practices.
} 
This evidence suggests that our findings are not driven by the choice to calculate AccSophistication as a linear sum of the three components of accounting sophistication. These findings also suggest that our results are predominantly driven by the use of accrual accounting. ${ }^{24}$

\subsection{The Moderating Role of Collateral}

We next partition our analysis by whether or not the firm pledged collateral for the loan. As discussed earlier, economic theories argue that collateral can be used to reduce adverse selection by acting as a sorting mechanism since only higher quality borrowers will be willing to pledge their assets (i.e., reducing adverse selection problems), or lowering moral hazard problems by providing incentives for borrowers to provide greater effort or abstain from shifting borrowed funds from lower-risk to higher-risk projects. Consistent with these theories, Bharath et al. (2009) find that the incentives to pledge collateral are strongest for the informational opaque, such as those with short lending relationships. If borrowers can reduce interest rates by pledging collateral rather than by reducing information asymmetries through the provision of more sophisticated accounting information (or through higher credit scores or longer banking relationships), then the benefits from accrual accounting should be lower on loans with collateral.

Consistent with this prediction, untabulated regression models show an accrual accounting benefit of -0.607 ( $p=0.04$, two-tailed) in firms that did not pledge collateral and $-0.199(p=0.29)$ in those pledging collateral. When we include multiplicative interaction terms in these models, the results continue to indicate that the benefits from accrual accounting are decreasing in both credit scores and relationship length, but that any benefits are lower or nonexistent in firms that pledge collateral. For example, the benefit from accrual accounting for a firm not pledging (pledging) collateral and having a credit score and relationship length at the 25th percentile is 103 (39) basis points, and 21 (0) basis points at a credit score and relationship length at the 75th percentile.

\footnotetext{
${ }^{24}$ We repeated our analyses using two other dichotomous variables representing the other levels of auditor association (review and compilation). The results are consistently weaker using this specification.
} 
The finding that collateral reduces any interest rate benefits from accrual accounting is reinforced when we estimate the models using categorical variables for accrual use or non-use, credit scores below or above the median, and relationship lengths above or below the median, thereby allowing for nonlinearities. As shown in Table 11, we find no significant differences in interest rate across the various classifications or their interactions in the subsample of loans with collateral. In contrast, accrual use has a significant, positive main effect on interest rates in loans without collateral, but any significant accrual accounting benefit in this subsample is again limited to borrowers with low credit scores and/or short relationship lengths. This evidence supports theories that contractual characteristics such as collateral can substitute for higher quality information when addressing information asymmetries in lending decisions.

\subsection{Other Moderating Factors}

The debt literature suggests that the age of the borrower's firm and its legal liability can also influence the level of information asymmetries. We examine the influence of firm age by partitioning our sample into firms that are younger or older than the sample median (15 years). Information asymmetries between borrowers and lenders are argued to be decreasing in firm age (Diamond 1989; Stiglitz and Weiss, 1981; Minnis, 2010). As information on firms becomes increasingly available over time, the value of greater accounting sophistication and longer lending relationships for reducing information asymmetries may decline as credit scores and other external information sources reflect a larger information set. In untabulated tests, we find an accrual accounting interest rate benefit of -0.642 in younger firms ( $p=0.03$, two-tailed) and an insignificant $0.180(p=0.35)$ in older firms, consistent with the benefits of accounting sophistication being greater for younger firms. We also find a significantly negative association between credit scores and interest rates in older firms $(\beta=-0.006, p=0.04)$ but not in younger firms, consistent with credit scores becoming more informative as they incorporate more firm history. 
Inclusion of the interaction terms reveals that the interest rate benefits from accrual accounting are decreasing in credit scores and relationship length, but only in younger firms. For example, the estimated benefit from accrual accounting in a firm younger than the sample median and with a credit score and relationship length at the $25^{\text {th }}$ percentile is 129 basis points relative to a younger firm with a credit score and relationship length at the $75^{\text {th }}$ percentile. However, there are no significant interaction effects in older firms, suggesting that the interest rate benefits from accrual accounting are primarily in younger firms with relatively low credit scores and short lending relationships.

Second, we partition our sample by the firm’s legal liability. Avery et al. (1998) argue that reducing information asymmetries is more important for lenders to limited liability firms since the borrowers' personal wealth is protected in the case of default. Consistent with this hypothesis, Allee and Yohn (2009) find that the use of accrual-based financial statements is associated with lower interest rates in small businesses with limited liability, but find no interest rate benefit in businesses with unlimited liability. Similarly, when we estimate interest rate models without the interaction terms, we find no significant benefit from accrual accounting ( $p=0.33$, two-tailed) in unlimited liability firms but a significant -0.379 rate reduction $(p=0.04)$ in limited liability firms (not reported in the tables). However, when we include the interaction terms, accrual accounting and its interactions become significant in both subsamples. In both limited and unlimited liability firms, the interest rate benefits from accrual accounting are again decreasing in both credit scores and relationship length. For example, the benefit from accrual accounting in an unlimited (limited) liability firm with a credit score and a relationship length at the $25^{\text {th }}$ percentile differs by 128 (64) basis points from a firm with a credit score and relationship length at the $75^{\text {th }}$ percentile. Thus, once the alternative information sources are incorporated into the analyses, accrual accounting exhibits 
potential interest rate benefits regardless of the borrowers' legal liability, with greater benefits in unlimited liability firms.

Our analyses of the influence of firm age and legal liability continue to support the finding that the use of accrual accounting can provide interest rate benefits, but that any benefits from this more sophisticated accounting method is decreasing in the firm’s credit score and relationship length. However, the results also suggest that firm age and legal liability moderate the relation between the various information sources (and their interactions) and interest rates.

\section{CONCLUSIONS}

This study examines whether accrual accounting, third-party credit scores, and the "soft" information provided by relationship banking interact to reduce information asymmetries between borrowers and lenders, thereby increasing the firm’s access to debt and lowering the firm's interest rate. We investigate this question using a large, representative sample of small, privately-held firms. The small firm setting has the advantage of having fewer competing information sources and no mandatory accounting practices that may affect observed associations between accounting sophistication and lending decisions. In contrast to prior small business lending studies, we provide evidence on whether alternative "hard" and "soft" information sources (accrual accounting, thirdparty credit scores, and relationship banking) are substitute means for reducing information asymmetries. In doing so, our study informs regulators and practitioners, as well as extending prior studies on the relative informativeness of accounting sophistication to the capital markets.

We find little evidence that accrual accounting reduces the likelihood of loan denial; however, higher credit scores are negatively associated with loan denial, suggesting that the information contained in these scores is used in the initial decision to accept or deny the application, while the incremental information from accrual accounting has little influence on this decision. In contrast, we 
find accrual accounting is negatively associated with the initial interest rate on approved loans, consistent with firm provided accounting reducing information asymmetries between lenders and borrowers.

Examining the complementary or substitutability between accounting sophistication (in our case accrual accounting), soft information, and third party credit scores on the borrower's cost of debt suggests that these alternative information sources are substitute means for assessing borrower risk and determining interest rates. We show that any interest rate benefits from accrual accounting in small firms is contingent on (diminishing in) the length of their existing banking relationships and publicly available creditworthiness. Further analyses suggest that accrual accounting only has a significant influence on interest rates in firms that have weak credit scores and short relationships with their lender, and vice versa. Moreover, any interest rate benefits from the alternative information sources appear to be eliminated when the borrower pledges collateral, supporting economic theories that collateral provides an alternative mechanism to deal with information asymmetries in lending decisions. Further examination of contingency factors suggests that firm age and legal liability further moderate the influence of the various information sources (and their interactions) on interest rates. Taken together, our findings suggest that although improvements in financial accounting sophistication in this setting can be beneficial, it is likely to benefit only a subset of small business borrowers and lenders. Overall, our study demonstrates the importance of evaluating the role of accounting information in the context of the firm's overall information environment, and of considering the role of debt contract characteristics when assessing the potential benefits from more sophisticated accounting information in lending decisions. 


\section{REFERENCES}

Akhavein, J., W. S. Frame, and L. White. 2005. The diffusion of financial innovation: An examination of the adoption of small business credit scoring by large banking organizations. Journal of Business 78: 577-596.

Allee, K. D., and T. L. Yohn. 2009. The demand for financial statements in an unregulated environment: An examination of the production and use of financial statements by privatelyheld small businesses. The Accounting Review 84: 1-25.

Ai, C. R., and E. C. Norton. 2003. Interaction terms in logit and probit models. Economics Letters 80: $123-129$.

Amemiya, T. 1985. Advanced Econometrics. Cambridge, MA: Harvard University Press.

American Institute of Certified Public Accountants (AICPA). 2004. Private Company Financial Reporting Study: Stratified Random Sample Executive Report. Omaha, NE: AICPA.

American Institute of Certified Public Accountants (AICPA) and Financial Accounting Standards Board (FASB). 2006. Enhancing the Financial Accounting and Reporting Standard-Setting Process for Private Companies. Norwalk, CT: FASB.

Armstrong, C., W. R. Guay, and J. Weber. 2010. The role of information and financial reporting in corporate governance and debt contracting. Working paper. University of Pennsylvania.

Avery, R., R. Bostic, and K. Samolyk. 1998. The role of personal wealth in small business finance. Journal of Banking and Finance 22: 1019-1062.

Baber, W. and A. Gore. 2008. Consequences of GAAP disclosure regulation: evidence from municipal debt issues. The Accounting Review 83: 565-592.

Baker, W. M., and G. M. Cunningham. 1993. Effects of small business accounting bases and accountant service levels on loan officer decisions. Journal of Business Finance and Accounting 20: 465-477.

Berger, A. N., and W. S. Frame. 2007. Small business credit scoring and credit availability. Journal of Small Business Management 45: 5-22.

Berger, A. N., W. S. Frame, and N. Miller. 2005. Credit scoring and the availability, price and risk of small business credit. Journal of Money, Credit, and Banking 37: 191-222.

Berger, A. N., and G. F. Udell. 1995. Relationship lending and lines of credit in small firm finance. Journal of Business 68: 351-381.

Berger, A.N., and G.F. Udell. 2006. A more complete conceptual framework for SME finance. Journal of Banking and Finance 30: 2945-2966. 
Berry, A. J., S. Faulkner, M. Hughes, and R. Jarvis. 1993. Financial information, the banker and the small business. British Accounting Review 25: 131-150.

Beyer, A., D. A. Cohen, T. Z. Lys, and B. R. Walther. 2010. The financial reporting environment: Review of the recent literature. Working paper. Northwestern University.

Bharath, S. T., S. Dahiya, A. Saunders, and A. Srinivasan. In press. Lending relationships and loan contract terms. Review of Financial Studies. doi:10.1093/rfs/hhp064

Bharath, S. T., J. Sunder, and S. V. Sunder. 2008. Accounting quality and debt contracting. The Accounting Review 83: 1-28.

Blackwell, D. W., T. R. Noland, and D. B. Winters. 1998. The value of auditor assurance: Evidence from loan pricing. Journal of Accounting Research 36: 57-70.

Botosan, C. A., H. Ashbaugh-Skaife, A. L. Beatty, P. Y. Davis-Friday, P. E. Hopkins, K. K. Nelson, K. Ramesh, R. Uhl, M. Venkatachalam, and G. Vrana. 2006. Financial accounting and reporting standards for private entities. Accounting Horizons 20: 179-194.

Brown, M., and C. Zehnder. 2007. Credit reporting, relationship banking, and loan repayment. Journal of Money, Credit and Banking 39: 1883-1918.

Butler, M., A. Kraft, and I. S. Weiss. 2007. The effect of reporting frequency on the timeliness of earnings: The cases of voluntary and mandatory interim reports. Journal of Accounting and Economics 43: 181-217.

Cassar, G. 2009. Financial statement and projection preparation in start-up ventures. The Accounting Review 84: 27-51.

Cassar, G. 2010. Discussion of the value of financial statement verification in debt financing: Evidence from private U.S. firms. Working paper. University of Pennsylvania.

Cavalluzzo, K. S., L. C. Cavalluzzo, and J. D. Wolken. 2002. Competition, small business financing, and discrimination: Evidence from a new survey. Journal of Business 75: 641-679.

Coco, G. 2000. On the use of collateral. Journal of Economic Surveys 14: 191-214.

Cole, R. 1998. The importance of relationships to the availability of credit. Journal of Banking and Finance 22: 959-977.

Cowen, C. D., and A. M. Cowen. 2006. A Survey Based Assessment of Financial Institution Use of Credit Scoring for Small Business Lending. Office of Advocacy, The United States Small Business Administration.

Danos, P., D. L. Holt, and E. A. Imhoff, Jr. 1989. The use of accounting information in bank lending decisions. Accounting, Organizations and Society 14: 235-246. 
Dechow, P. M. 1994. Accounting earnings and cash flows as measures of firm performance: The role of accounting accruals. Journal of Accounting and Economics 18: 3-42.

Dechow, P., G. Weili, and C. Schrand. In press. Understanding earnings quality: A review of the proxies, their determinants and their consequences. Journal of Accounting and Economics. doi:10.1016/j.jacceco.2010.09.001

DeFond, M. L., and M. Hung. 2003. An empirical analysis of analysts' cash flow forecasts. Journal of Accounting and Economics 35: 73-100.

Diamond, D.W., 1989. Reputation acquisition in debt markets. Journal of Political Economy 97, 828-862.

Diamond, D. 1991. Monitoring and reputation: The choice between bank loans and directly placed debt. Journal of Political Economy 99: 688-721.

Federal Reserve Board (FRB). 2006. 2003 Survey of Small Business Finances: Technical Codebook. Washington, DC: FRB.

Financial Accounting Standards Board (FASB). 1978. Statement of Financial Accounting Concepts No.1. Norwalk, CT: FASB.

Frame, W. S, A. Srinivasan, and L. Woosley. 2001. The effect of credit scoring on small-business lending. Journal of Money, Credit and Banking 33: 813-825.

Francis, J. R., R. LaFond, P. Olsson, and K. Schipper. 2005. The market pricing of accruals quality. Journal of Accounting and Economics 39: 295-327.

Greenbaum, S., G. Kanastas, and I. venezia. 1989. Equilibrium loan pricing under bank-client relationship. Journal of Banking and Finance 13: 221-235.

Guenther, D. A., E. L. Maydew, and S. E. Nutter. 1997. Financial reporting, tax costs, and book-tax conformity. Journal of Accounting \& Economics 23: 225-248.

Hanlon, M., E. Maydew, and T. Shevlin. 2006. Book-tax conformity and the informativeness of earnings. Working paper, University of Michigan, University of North Carolina, and University of Washington.

Heckman, J. J. 1976. The common structure of statistical models of truncation, sample selection and limited dependent variables and a simple estimator for such models. Annals of Economic \& Social Measurement 5: 475-492.

Internal Revenue Service (IRS). 1999. Publication 538: Accounting periods and methods. Washington, DC: Department of Treasury.

International Accounting Standards Board (IASB). 2007. International Financial Reporting Standard for Small and Medium-sized Entities. London, UK: IASB. 
International Federation of Accountants (IFA). 2006. Micro-Entity Financial Reporting: Perspectives of Preparers and Users. New York, NY: IFA.

Jones, S. 1998. An evaluation of user ratings of cash vs accrual based financial reports in Australia. Managerial Finance 24: 16-28.

Jones, S., R. A. Romano, and K. X. Smyrnios. 1995. An evaluation of the decision usefulness of cash flow statements by Australian reporting entities. Accounting and Business Research 25: 115-129.

Jones, S., and L. Widjaja. 1998. The decision relevance of cash-flow information: A note. Abacus 34: 204-219.

Kallberg, J.G., and G.F. Udell. 2003. The value of private sector business credit information sharing: the US case. Journal of Banking and Finance 27: 449-469.

Kennedy, P. 2003. A Guide to Econometrics. (5th ed). Cambridge, MA: MIT Press.

Kim, J-B, D. Simunic; M., Stein, and C. Yi. 2007. Voluntary audits and the cost of debt capital for privately-held firms: Korean evidence. Working paper. City University of Hong Kong.

Larcker, D., and T. Rusticus. 2010. On the use of instrumental variables in accounting research. Journal of Accounting and Economics 49: 186-205.

Lee. T. A. 1993. Cash Flow Reporting: A Recent History of an Accounting Practice. (Eds) New York, NY: Garland.

Louis, H., and D. Robinson. 2005. "Do managers credibly use accruals to signal private information? Evidence from the pricing of discretionary accruals around stock splits. Journal of Accounting and Economics 39: 361-380.

Minnis, M. 2010. The value of financial statement verification in debt financing: Evidence from private firms. Working paper, University of Chicago.

Nair, R. D., and L. E. Rittenberg. 1983. Alternative accounting principles for smaller businesses: Proposals and analysis. Journal of Commercial Bank Lending (April): 2-21.

Ongena, S., and D.C. Smith. 2001. The duration of bank relationships. Journal of Financial Economics 61: 449-475.

Petersen, M.A. 2004. Information: Hard and soft. Working paper, Northwestern University.

Petersen, M. A., and R. G. Rajan. 1994. The benefits of lending relationships: Evidence from small business data. Journal of Finance 49: 3-37.

Petersen, M. A., and R. G. Rajan. 2002. Does distance still matter? The information revolution in small business lending. Journal of Finance 57: 2533-2570. 
Previts, G., R. Bricker, T. Robinson, and S. Young. 1994. A content analysis of sell-side financial analyst company reports. Accounting Horizons 8: 55-70.

Riahi-Belkaoui, A. 1992. Accrual accounting, modified cash basis of accounting and the loan decision: An experiment in functional fixation. Managerial Finance 18: 3-13.

Sengupta, P. 1998. Corporate disclosure quality and the cost of debt. The Accounting Review 73: 459-474.

Sharma, D. S., and E. R. Iselin. 2003. The decision usefulness of reported cash flow and accrual information in a behavioural field experiment. Accounting and Business Research 33: 123135.

Sharpe, S.A. 1990. Asymmetric information, bank lending and implicit contracts: a stylized model of customer relationships. Journal of Finance 45: 1069-1087.

Steijvers, T. and W. Voordeckers. 2009. Collateral and credit rationing: a review of recent empirical studies as a guide for future research. Journal of Economic Surveys 23: 924-946.

Stiglitz, J. E., and A. Weiss. 1981. Credit rationing in markets with imperfect information. The American Economic Review 71, 393-410.

Stock, J. H., J. H. Wright, and M. Yogo. 2002. A survey of weak instruments and weak identification in generalized method of moments. Journal of Business and Statistics 20: 518-529. 
Table 1

Sample selection

\begin{tabular}{lr}
\hline & Firms \\
\hline Survey of Small Business Finances sample & 4,240 \\
$\quad$ Minus & 508 \\
$\quad$ Firms with non-positive assets, sales, shareholders & 5 \\
$\quad$ Publicly traded firms & 351 \\
$\quad$ Corporations (other than S) with annual receipts above \$5 million & 83 \\
$\quad$ Respondents with missing accounting choice & 3,293 \\
Firms available for analysis & 1,402 \\
Firms that recently applied for debt financing & 17 \\
$\quad$ Minus & 1,385 \\
$\quad$ Respondents with missing responses to any independent variable & 1,309 \\
Sample used in loan denial analysis & 88 \\
Firms with recent debt financing & 30 \\
$\quad$ Minus & \\
$\quad$ Respondents with missing interest rate & 1,191 \\
Respondents with missing responses to any independent variable & \\
\hline
\end{tabular}


Table 2

Descriptive statistics and variable definitions

Panel A: Descriptive statistics, full sample

\begin{tabular}{|c|c|c|c|c|c|c|}
\hline Variable & $\mathrm{N}$ & Mean & Std. dev. & First quartile & Median & Third quartile \\
\hline Accrual & 3,293 & 0.36 & 0.48 & 0.00 & 0.00 & 1.00 \\
\hline Credit score & 3,271 & 58.97 & 29.55 & 38.00 & 63.00 & 88.00 \\
\hline Log total assets & 3,290 & 5.17 & 1.02 & 4.49 & 5.16 & 5.89 \\
\hline Owner manager & 3,272 & 0.92 & 0.28 & 1.00 & 1.00 & 1.00 \\
\hline Log number of owners & 3,293 & 0.22 & 0.29 & 0.00 & 0.30 & 0.30 \\
\hline Family owned & 3,290 & 0.85 & 0.36 & 1.00 & 1.00 & 1.00 \\
\hline Corporation & 3,293 & 0.59 & 0.49 & 0.00 & 1.00 & 1.00 \\
\hline Cash to assets & 3,211 & 0.24 & 0.29 & 0.03 & 0.12 & 0.36 \\
\hline Firm age & 3,265 & 15.90 & 11.84 & 7.00 & 14.00 & 23.00 \\
\hline Sales growth (1 year) & 3,274 & 0.43 & 0.50 & 0.00 & 0.00 & 1.00 \\
\hline Sales growth (3 years) & 3,247 & 0.47 & 0.50 & 0.00 & 0.00 & 1.00 \\
\hline Trade credit & 3,293 & 0.69 & 0.46 & 0.00 & 1.00 & 1.00 \\
\hline Accounts receivable & 3,293 & 0.61 & 0.49 & 0.00 & 1.00 & 1.00 \\
\hline Apply & 3,293 & 0.43 & 0.50 & 0.00 & 0.00 & 1.00 \\
\hline
\end{tabular}

Panel B: Descriptive statistics, denial sample

\begin{tabular}{|c|c|c|c|c|c|c|}
\hline Variable & $\mathrm{N}$ & Mean & Std. dev. & First quartile & Median & Third quartile \\
\hline Denied & 1,385 & 0.11 & 0.31 & 0.00 & 0.00 & 0.00 \\
\hline Accrual & 1,385 & 0.49 & 0.50 & 0.00 & 0.00 & 1.00 \\
\hline Credit score & 1,385 & 59.20 & 29.78 & 38.00 & 63.00 & 88.00 \\
\hline Log total assets & 1,385 & 5.64 & 0.90 & 5.03 & 5.67 & 6.27 \\
\hline Return on assets & 1,385 & 0.66 & 1.83 & 0.01 & 0.15 & 0.57 \\
\hline Asset turnover & 1,385 & 4.86 & 7.08 & 1.42 & 2.84 & 5.00 \\
\hline Debt to assets & 1,385 & 0.87 & 1.08 & 0.28 & 0.60 & 0.97 \\
\hline Firm age & 1,385 & 16.86 & 12.35 & 8.00 & 15.00 & 23.00 \\
\hline Bankrupt & 1,385 & 0.01 & 0.12 & 0.00 & 0.00 & 0.00 \\
\hline Judgment & 1,385 & 0.05 & 0.21 & 0.00 & 0.00 & 0.00 \\
\hline Personal delinquency & 1,385 & 0.08 & 0.27 & 0.00 & 0.00 & 0.00 \\
\hline Firm delinquency & 1,385 & 0.20 & 0.40 & 0.00 & 0.00 & 0.00 \\
\hline
\end{tabular}

Panel C: Descriptive statistics, interest rate sample

\begin{tabular}{lrrrrrr} 
Variable & $\mathrm{N}$ & Mean & Std. dev. & First quartile & Median & Third quartile \\
\hline Interest rate & 1,191 & 5.97 & 2.81 & 4.50 & 5.90 & 7.00 \\
Accrual & 1,191 & 0.50 & 0.50 & 0.00 & 1.00 & 1.00 \\
Credit score & 1,191 & 60.70 & 29.34 & 38.00 & 63.00 & 88.00 \\
Relationship & 1,191 & 0.78 & 0.46 & 0.45 & 0.81 & 1.14 \\
Prime rate & 1,191 & 4.39 & 0.74 & 4.00 & 4.22 & 4.58 \\
Duration spread & 1,191 & 2.41 & 0.42 & 2.11 & 2.28 & 2.68 \\
Term premium & 1,191 & 0.60 & 0.95 & 0.00 & 0.00 & 1.00 \\
Debt to assets & 1,191 & 0.82 & 0.99 & 0.28 & 0.59 & 0.95 \\
Fixed rate & 1,191 & 0.49 & 0.50 & 0.00 & 0.00 & 1.00 \\
Log total assets & 1,191 & 5.69 & 0.89 & 5.08 & 5.70 & 6.32 \\
Log amount & 1,191 & 5.09 & 0.80 & 4.48 & 5.00 & 5.60 \\
Collateral & 1,191 & 0.53 & 0.50 & 0.00 & 1.00 & 1.00 \\
Primary institution & 1,191 & 0.74 & 0.44 & 0.00 & 1.00 & 1.00 \\
& & & & & & \\
\hline
\end{tabular}


Variables Description

Accounts receivable An indicator variable taking the value of one if the firm records sales on account, zero otherwise

Accrual

Apply

An indicator variable taking the value of one if the firm uses accrual accounting, zero otherwise

An indicator variable taking the value of one if the firm applied for a loan in the previous three years, zero otherwise

Asset turnover $^{\text {a }} \quad$ Sales divided by total assets

Bankrupt

An indicator variable taking the value of one if the firm or owner declared bankruptcy in the past seven years, zero otherwise

Cash to assets ${ }^{\text {a }}$

Collateral

Corporation

Credit score

Debt to assets ${ }^{\mathrm{a}}$

Denied

Total cash divided by total assets

An indicator variable taking the value of one if collateral is provided for the loan, zero otherwise

An indicator variable taking the value of one if the entity was a corporation, zero otherwise

Dun \& Bradstreet credit score

Total debt divided by total assets

An indicator variable taking the value of one if firm was denied credit at least one in the last three years, zero otherwise

Duration spread

Family owned

Difference between Baa bond and yield on 10-year treasury bonds at the time of the loan

An indicator variable taking the value of one if more than 50 percent of equity is owned by a single family, zero otherwise

Firm age

Firm delinquency

Age of the firm in years

An indicator variable taking the value of one if the firm was delinquent on obligations one or more times in the past three years, zero otherwise

Fixed rate

An indicator variable taking the value of one if the interest rate on the loan is fixed (rather than variable), zero otherwise

Interest rate

Judgment

Interest rate on most recent loan

An indicator variable taking the value of one if the firm or owner has any judgments against it in the past three years, zero otherwise

Log amount $\quad \log 10$ of the loan amount

Log number of owners Log 10 of the number of owners/partners/shareholders

Log total assets $\quad \log 10$ of the firm's total assets

Owner manager $\quad$ An indicator variable taking the value of one if the firm is managed by an owner, zero otherwise

Personal delinquency An indicator variable taking the value of one if the owner was delinquent on personal obligations one or more times in the past three years, zero otherwise

Primary institution An indicator variable taking the value of one if the debt is obtained from the firm's primary financial institution, zero otherwise

Prime rate The prime rate at the start of the loan

Relationship $\quad$ Log 10 the number of years the firm had conducted business with the lending institution at the time of the most recently approved loan application

Return on assets ${ }^{\mathrm{a}} \quad$ Profit divided by total assets

Sales growth (1 year) An indicator variable taking the value of one if the firm's total sales were greater than the previous year, zero otherwise

Sales growth (3 years) An indicator variable taking the value of one if the firm's total sales were greater than three years earlier, zero otherwise

Trade credit An indicator variable taking the value of one if the firm records purchases on account, zero otherwise

Term premium Difference between yield on government bond with similar maturity and yield on treasury bill

\footnotetext{
${ }^{\mathrm{a}}$ Ratios winsorized at 2.5 percent and 97.5 percent.
} 
Table 3

Correlations

Panel A: Loan denial sample

\begin{tabular}{|c|c|c|c|c|c|c|c|c|c|c|c|}
\hline Variable & Denied & Accrual & Credit score & $\begin{array}{c}\text { Log total } \\
\text { assets }\end{array}$ & $\begin{array}{c}\text { Asset } \\
\text { turnover }\end{array}$ & $\begin{array}{c}\text { Return on } \\
\text { assets }\end{array}$ & $\begin{array}{c}\text { Debt-to- } \\
\text { assets }\end{array}$ & Firm age & Bankrupt & Judgment & $\begin{array}{c}\text { Personal } \\
\text { delinquency }\end{array}$ \\
\hline \multicolumn{12}{|l|}{ Denied } \\
\hline Accrual & $-0.10 * *$ & & & & & & & & & & \\
\hline Credit score & $-0.10 * *$ & $0.06^{*}$ & & & & & & & & & \\
\hline Log total assets & $-0.24 * *$ & $0.45 * *$ & $0.12 * *$ & & & & & & & & \\
\hline Asset turnover & $-0.16 * *$ & $-0.12 * *$ & 0.04 & $-0.45^{* *}$ & & & & & & & \\
\hline Return on assets & 0.00 & $-0.15^{* *}$ & -0.02 & $-0.31 * *$ & $0.54 * *$ & & & & & & \\
\hline Debt to assets & -0.01 & -0.04 & $-0.08 * *$ & $-0.31^{* *}$ & $0.41^{* *}$ & $0.17^{* *}$ & & & & & \\
\hline Firm age & $0.12 * *$ & $0.07 * *$ & $0.16^{* *}$ & $-0.24^{* *}$ & -0.05 & -0.02 & $-0.13^{* *}$ & & & & \\
\hline Bankrupt & $-0.13^{* *}$ & $-0.07 * *$ & $-0.12 * *$ & $-0.09 * *$ & -0.02 & 0.01 & 0.02 & -0.01 & & & \\
\hline Judgment & $0.11^{* *}$ & -0.04 & $-0.11 * *$ & -0.02 & 0.03 & -0.00 & $0.09 * *$ & -0.02 & $0.09 * *$ & & \\
\hline Personal delinquency & $0.14^{* *}$ & $-0.11 * *$ & $-0.20 * *$ & $-0.16^{* *}$ & -0.01 & -0.02 & $0.07 * *$ & $-0.10 * *$ & $0.10 * *$ & $0.28 * *$ & \\
\hline Firm delinquency & $0.27 * *$ & $0.08^{* *}$ & $-0.33 * *$ & 0.02 & -0.04 & -0.03 & $0.13^{* *}$ & -0.03 & 0.05 & $0.19^{* *}$ & $0.30 * *$ \\
\hline
\end{tabular}

Variables are defined in Table $2 .{ }^{* *} \mathrm{p}<0.01 ;{ }^{*} \mathrm{p}<0.05 ; \mathrm{n}=1,385$

\section{Panel B: Cost of debt sample}

\begin{tabular}{|c|c|c|c|c|c|c|c|c|c|c|c|c|}
\hline Variable & $\begin{array}{c}\text { Interest } \\
\text { rate }\end{array}$ & Accrual & Credit score & Relationship & $\begin{array}{c}\text { Prime } \\
\text { rate }\end{array}$ & $\begin{array}{c}\text { Duration } \\
\text { spread }\end{array}$ & $\begin{array}{c}\text { Term } \\
\text { premium }\end{array}$ & $\begin{array}{c}\text { Debt-to- } \\
\text { assets }\end{array}$ & Fixed rate & $\begin{array}{c}\text { Log total } \\
\text { assets }\end{array}$ & $\begin{array}{c}\text { Log } \\
\text { amount }\end{array}$ & Collateral \\
\hline \multicolumn{13}{|l|}{ Interest rate } \\
\hline Accrual & $-0.20 * *$ & & & & & & & & & & & \\
\hline Credit score & $-0.09 * *$ & $0.06^{*}$ & & & & & & & & & & \\
\hline Relationship & $-0.08 * *$ & 0.03 & $0.11^{* *}$ & & & & & & & & & \\
\hline Prime rate & $0.06^{*}$ & -0.01 & 0.00 & -0.02 & & & & & & & & \\
\hline Duration spread & $0.07 *$ & -0.03 & -0.02 & $-0.11 * *$ & $0.21 * *$ & & & & & & & \\
\hline Term premium & $0.15^{* *}$ & $-0.09 * *$ & -0.04 & $-0.13^{* *}$ & -0.05 & $0.09 * *$ & & & & & & \\
\hline Debt to assets & $0.10 * *$ & -0.03 & $-0.08 * *$ & $-0.10 * *$ & -0.04 & 0.01 & -0.02 & & & & & \\
\hline Fixed rate & $0.27 * *$ & $-0.10 * *$ & -0.04 & $-0.08 * *$ & $0.12^{* *}$ & $0.13^{* *}$ & $0.65^{* *}$ & -0.03 & & & & \\
\hline Log total assets & $-0.31 * *$ & $0.44^{* *}$ & $0.10^{* *}$ & $0.14^{* *}$ & -0.04 & $-0.12 * *$ & $-0.14^{* *}$ & $-0.29 * *$ & $-0.26 * *$ & & & \\
\hline Log amount & $-0.33^{* *}$ & $0.36 * *$ & $0.12 * *$ & $0.06 *$ & -0.06 & $-0.09 * *$ & $-0.18 * *$ & -0.05 & $-0.39 * *$ & $0.74^{* *}$ & & \\
\hline Collateral & $-0.12 * *$ & $0.12 * *$ & -0.01 & $-0.07^{*}$ & 0.02 & $0.07^{*}$ & $0.10 * *$ & 0.02 & -0.04 & $0.20 * *$ & $0.30 * *$ & \\
\hline Primary institution & -0.07 & $0.14 * *$ & 0.04 & $0.34^{* *}$ & -0.04 & -0.05 & $-0.19 * *$ & -0.01 & $-0.18 * *$ & $0.13^{* *}$ & $0.18 * *$ & 0.03 \\
\hline
\end{tabular}

Variables are defined in Table 2. ${ }^{* *} \mathrm{p}<0.01 ;{ }^{*} \mathrm{p}<0.05 ; \mathrm{n}=1,191$ 
Table 4

Determinants of the use of accrual accounting

\begin{tabular}{|c|c|c|c|c|}
\hline \multirow[b]{2}{*}{ Independent variables } & \multicolumn{2}{|c|}{ Instruments Only } & \multicolumn{2}{|c|}{ All Exogenous Variables } \\
\hline & Coefficient & Std. error & Coefficient & Std. error \\
\hline Days in inventory & $0.003^{* * *}$ & 0.001 & $0.002 * * *$ & 0.001 \\
\hline Accounts receivable & $1.041^{* * *}$ & 0.051 & $0.629 * * *$ & 0.059 \\
\hline Log of total assets & & & $0.671^{* * *}$ & 0.035 \\
\hline Return on assets & & & -0.007 & 0.014 \\
\hline Asset turnover & & & $0.015^{* * *}$ & 0.004 \\
\hline Debt to assets & & & $0.140 * * *$ & 0.025 \\
\hline Firm age & & & -0.003 & 0.002 \\
\hline Bankrupt & & & 0.096 & 0.185 \\
\hline Judgment & & & $-0.188 *$ & 0.133 \\
\hline Personal delinquency & & & $-0.188^{*}$ & 0.100 \\
\hline Firm delinquency & & & $0.146^{*}$ & 0.076 \\
\hline Credit score & & & 0.000 & 0.001 \\
\hline Intercept & $-1.108 * * *$ & 0.046 & $-4.532 * * *$ & 0.198 \\
\hline $\mathrm{N}$ & \multicolumn{2}{|c|}{3,292} & \multicolumn{2}{|c|}{3,197} \\
\hline Log likelihood & \multicolumn{2}{|c|}{-1913.13} & \multicolumn{2}{|c|}{-1603.85} \\
\hline Pseudo $\mathrm{R}^{2}$ & \multicolumn{2}{|c|}{.113} & \multicolumn{2}{|c|}{.234} \\
\hline$\chi^{2}$ & \multicolumn{2}{|c|}{$487.09 * * *$} & \multicolumn{2}{|c|}{$978.34 * * *$} \\
\hline \multicolumn{5}{|c|}{$\begin{array}{l}\text { Accrual }=\alpha+\beta_{1} \text { Days in inventory }+\beta_{2} \text { Accounts receivable }+\beta_{3} \text { Log of total assets }+ \\
\beta_{4} \text { Return on assets }+\beta_{5} \text { Asset turnover }+\beta_{6} \text { Debt to assets }+\beta_{7} \text { Firm age }+\beta_{8} \text { Bankrupt }+ \\
\beta_{9} \text { Judgment }+\beta_{10} \text { Personal delinquency }+\beta_{11} \text { Firm delinquency }+\beta_{12} \text { Judgment }+ \\
\beta_{13} \text { Personal delinquency }+\beta_{14} \text { Firm delinquency }+\beta_{15} \text { Credit score } \\
\text { Table reports probit estimation. Dependent variable is coded one if the entity uses } \\
\text { accrual accounting, and zero otherwise. Variables are defined in Table } 2 . * * *, * *, \\
\text { denote significance at } 1,5 \text { and } 10 \text { percent level (two-tailed), respectively. }\end{array}$} \\
\hline
\end{tabular}


Table 5

Determinants of applying for a loan

\begin{tabular}{lcc}
\hline Independent variables & Coefficient & Std. error \\
\hline Log total assets & $0.484^{* * *}$ & 0.033 \\
Owner manager & $0.202^{* *}$ & 0.089 \\
Log number of owners & $0.271^{* * *}$ & 0.099 \\
Cash to assets & $-0.745^{* * *}$ & 0.103 \\
Return on assets & 0.006 & 0.012 \\
Firm age & -0.001 & 0.002 \\
Sales growth (1 year) & $0.153^{* * *}$ & 0.056 \\
Sales growth (3 years) & 0.043 & 0.056 \\
Intercept & $-2.861^{* * *}$ & 0.203 \\
& & \\
$\mathrm{~N}$ & \multicolumn{2}{c}{3,090} \\
Log likelihood & $-1,792.64$ & \\
Pseudo $\mathrm{R}^{2}$ & 0.149 & \\
$\chi^{2}$ & \multicolumn{2}{c}{632.02} \\
\end{tabular}

Apply $=\alpha+\beta_{1} \log$ total assets $+\beta_{2}$ Owner manager $+\beta_{3}$ Log number of owners + $\beta_{4}$ Cash to assets $+\beta_{5}$ Return on assets $+\beta_{6}$ Firm age $+\beta_{7}$ Sales growth (1 year) $+\beta_{8}$ Sales growth (3 years)

Table reports probit estimation. Dependent variable is coded one if the entity has applied for a loan in the last three years, and zero otherwise. Independent variables are defined in Table 2. ***, **, * denote significance at 1,5 and 10 percent level (twotailed), respectively. 
Table 6

Determinants of loan denial

\begin{tabular}{|c|c|c|c|c|c|c|c|c|}
\hline \multirow[b]{2}{*}{ Independent variables } & \multicolumn{2}{|c|}{ Model 1} & \multicolumn{2}{|c|}{ Model 2} & \multicolumn{2}{|c|}{ Model 3} & \multicolumn{2}{|c|}{ Model 4} \\
\hline & Coefficient & Std. error & Coefficient & Std. error & Coefficient & Std. error & Coefficient & Std. error \\
\hline Accrual & -0.147 & 0.116 & -0.067 & 0.201 & & & & \\
\hline Credit score & $-0.010 * * *$ & 0.002 & $-0.009 * * *$ & 0.002 & $-0.009 * * *$ & 0.002 & $-0.011^{* * *}$ & 0.002 \\
\hline Accrual $\times$ Credit score & & & -0.002 & 0.004 & & & & \\
\hline Accrual_hat & & & & & -0.608 & 0.444 & -0.041 & 0.214 \\
\hline Accrual_hat $\times$ Credit score & & & & & & & -0.004 & 0.003 \\
\hline Log of total assets & $-0.689 * * *$ & 0.167 & $-0.685^{* * *}$ & 0.167 & $-0.553^{* * *}$ & 0.210 & $-0.584 * * *$ & 0.198 \\
\hline Return on assets & -0.029 & 0.033 & -0.029 & 0.033 & -0.034 & 0.033 & -0.026 & 0.033 \\
\hline Asset turnover & -0.005 & 0.009 & -0.005 & 0.009 & -0.001 & 0.009 & -0.003 & 0.009 \\
\hline Debt to assets & $0.100 * *$ & 0.046 & $0.101^{* *}$ & 0.046 & $0.117 * *$ & 0.047 & $0.126^{* *}$ & 0.052 \\
\hline Firm age & $-0.011 * *$ & 0.005 & $-0.011^{* *}$ & 0.005 & $-0.011^{* *}$ & 0.005 & $-0.011 * *$ & 0.005 \\
\hline Bankrupt & 0.456 & 0.319 & 0.464 & 0.319 & 0.423 & 0.319 & 0.496 & 0.319 \\
\hline Judgment & 0.138 & 0.213 & 0.136 & 0.212 & 0.081 & 0.218 & 0.127 & 0.215 \\
\hline Personal delinquency & $0.651 * * *$ & 0.157 & $0.651 * * *$ & 0.156 & $0.612^{* * *}$ & 0.164 & $0.641 * * *$ & 0.159 \\
\hline Firm delinquency & 0.152 & 0.130 & 0.146 & 0.131 & 0.202 & 0.134 & 0.154 & 0.136 \\
\hline Inverse mills ratio & $-1.373^{* * *}$ & 0.422 & $-1.367 * * *$ & 0.422 & $-1.370^{* * *}$ & 0.416 & $-1.435^{* * *}$ & 0.426 \\
\hline Intercept & $4.195^{* * *}$ & 1.207 & $4.141^{* * *}$ & 1.211 & $3.906^{* * *}$ & 1.310 & $3.559 * * *$ & 1.350 \\
\hline $\mathrm{N}$ & \multicolumn{2}{|c|}{1,308} & \multicolumn{2}{|c|}{1,308} & \multicolumn{2}{|c|}{1,307} & \multicolumn{2}{|c|}{1,307} \\
\hline Log likelihood & \multicolumn{2}{|c|}{-370.40} & \multicolumn{2}{|c|}{-370.28} & \multicolumn{2}{|c|}{-369.05} & \multicolumn{2}{|c|}{-368.35} \\
\hline Pseudo $\mathrm{R}^{2}$ & \multicolumn{2}{|c|}{0.183} & \multicolumn{2}{|c|}{0.184} & \multicolumn{2}{|c|}{0.182} & \multicolumn{2}{|c|}{0.184} \\
\hline$\chi^{2}$ & \multicolumn{2}{|c|}{166.19} & \multicolumn{2}{|c|}{166.42} & \multicolumn{2}{|c|}{164.03} & \multicolumn{2}{|c|}{165.88} \\
\hline \multicolumn{9}{|c|}{$\begin{array}{l}\text { Denial }=\alpha+\beta_{1} \text { Accrual }+\beta_{2} \text { Credit score }+\beta_{3} \text { Accrual } \times \text { Credit score }+\beta_{4} \text { Accrual_hat }+\beta_{5} \text { Accrual_hat } \times \text { Credit score }+\beta_{6} \text { Log of total assets }+ \\
\beta_{7} \text { Return on assets }+\beta_{8} \text { Asset turnover }+\beta_{9} \text { Debt to assets }+\beta_{10} \text { Firm age }+\beta_{11} \text { Bankrupt }+\beta_{12} \text { Judgment }+\beta_{13} \text { Personal delinquency }+\beta_{14} \text { Firm } \\
\text { delinquency }+\beta_{15} \text { Inverse mills ratio } \\
\text { Table reports probit estimation. Dependent variable is coded one if the entity was denied credit on a loan application in the last three years, and } \\
\text { zero otherwise. Accrual_hat is an instrumental variable of voluntary accrual use is based on probit model from Table } 4 \text {. Inverse mills ratio is } \\
\text { based on probit model for applying for a loan from Table } 5 \text {. All remaining independent variables are defined in Table } 2 . * * *, * *, * \text { denote } \\
\text { significance at } 1,5 \text { and } 10 \text { percent level (two-tailed), respectively. }\end{array}$} \\
\hline
\end{tabular}


Table 7

Determinants of interest rates with interactions

\begin{tabular}{|c|c|c|c|c|c|c|c|c|c|c|}
\hline \multirow[b]{2}{*}{ Independent variables } & \multicolumn{2}{|c|}{ Model 1} & \multicolumn{2}{|c|}{ Model 2} & \multicolumn{2}{|c|}{ Model 3} & \multicolumn{2}{|c|}{ Model 4} & \multicolumn{2}{|c|}{ Model 5} \\
\hline & Coefficient & Std. error & Coefficient & Std. error & Coefficient & Std. error & Coefficient & Std. error & Coefficient & Std. error \\
\hline Accrual & $-0.373^{* *}$ & 0.168 & $-1.004 * * *$ & 0.352 & $-0.664 * *$ & 0.305 & $-0.392 * *$ & 0.169 & $-1.196 * * *$ & 0.416 \\
\hline Credit score & -0.003 & 0.003 & $-0.008^{* *}$ & 0.004 & -0.003 & 0.003 & $-0.010^{* *}$ & 0.005 & $-0.015^{* * *}$ & 0.006 \\
\hline Relationship & -0.265 & 0.176 & $-0.290 *$ & 0.176 & $-0.449 *$ & 0.239 & $-0.864 * *$ & 0.381 & $-0.995 * *$ & 0.401 \\
\hline Accrual $\times$ Credit score & & & $0.010 * *$ & 0.005 & & & & & $0.010 * *$ & 0.005 \\
\hline Accrual × Relationship & & & & & 0.372 & 0.326 & & & 0.245 & 0.329 \\
\hline Credit score $\times$ Relationship & & & & & & & $0.010^{*}$ & 0.005 & $0.009 *$ & 0.005 \\
\hline Prime rate & 0.129 & 0.105 & 0.133 & 0.105 & 0.124 & 0.105 & 0.129 & 0.105 & 0.130 & 0.105 \\
\hline Duration spread & 0.054 & 0.187 & 0.060 & 0.186 & 0.067 & 0.187 & 0.058 & 0.186 & 0.072 & 0.187 \\
\hline Term premium & 0.025 & 0.117 & 0.014 & 0.117 & 0.002 & 0.117 & 0.019 & 0.117 & 0.005 & 0.117 \\
\hline Debt to assets & $0.151^{*}$ & 0.082 & $0.152 *$ & 0.082 & $0.149 *$ & 0.082 & $0.152^{*}$ & 0.082 & $0.152 *$ & 0.082 \\
\hline Fixed rate & $1.205^{* * *}$ & 0.217 & $1.222 * * *$ & 0.217 & $1.204^{* * *}$ & 0.217 & $1.205^{* * *}$ & 0.216 & $1.225^{* * *}$ & 0.216 \\
\hline Log total assets & -0.150 & 0.143 & -0.152 & 0.143 & -0.152 & 0.143 & -0.147 & 0.143 & -0.151 & 0.143 \\
\hline Log amount & $-0.765^{* * *}$ & 0.162 & $-0.758 * * *$ & 0.162 & $-0.762 * * *$ & 0.162 & $-0.769 * * *$ & 0.162 & $-0.762 * * *$ & 0.162 \\
\hline Collateral & $-0.274 *$ & 0.163 & $-0.271 *$ & 0.163 & $-0.278 *$ & 0.163 & -0.267 & 0.163 & -0.267 & 0.163 \\
\hline Primary institution & 0.119 & 0.185 & 0.125 & 0.185 & 0.136 & 0.186 & 0.119 & 0.185 & 0.136 & 0.185 \\
\hline Intercept & $10.089 * * *$ & 0.903 & $10.345^{* * *}$ & 0.910 & $10.230^{* * *}$ & 0.911 & $10.538^{* * *}$ & 0.937 & $10.868^{* * *}$ & 0.948 \\
\hline Loan type indicators & \multicolumn{2}{|c|}{ Yes } & \multicolumn{2}{|c|}{ Yes } & \multicolumn{2}{|c|}{ Yes } & \multicolumn{2}{|c|}{ Yes } & \multicolumn{2}{|c|}{ Yes } \\
\hline $\mathrm{N}$ & \multicolumn{2}{|c|}{1,189} & \multicolumn{2}{|c|}{1,189} & \multicolumn{2}{|c|}{1,189} & \multicolumn{2}{|c|}{1,189} & \multicolumn{2}{|c|}{1,189} \\
\hline $\mathrm{R}^{2}$ & \multicolumn{2}{|c|}{0.185} & \multicolumn{2}{|c|}{0.188} & \multicolumn{2}{|c|}{0.186} & \multicolumn{2}{|c|}{0.187} & \multicolumn{2}{|c|}{0.191} \\
\hline F-stat & \multicolumn{2}{|c|}{15.653} & \multicolumn{2}{|c|}{15.054} & \multicolumn{2}{|c|}{14.860} & \multicolumn{2}{|c|}{14.985} & \multicolumn{2}{|c|}{13.761} \\
\hline F-stat for interactions & & & & & & & & & 2.6 & \\
\hline
\end{tabular}

Interest rate $=\alpha+\beta_{1}$ Accrual $+\beta_{2}$ Credit score $+\beta_{3}$ Relationship $+\beta_{4}$ Accrual $\times$ Credit score $+\beta_{5}$ Accrual $\times$ Relationship $+\beta_{6}$ Credit score $\times$ Relationship $+\beta_{7}$ Prime rate + $\beta_{8}$ Duration spread $+\beta_{9}$ Term premium $+\beta_{10}$ Debt to assets $+\beta_{11}$ Fixed rate $+\beta_{12}$ Log total assets $+\beta_{13}$ Log amount $+\beta_{14}$ Collateral $+\beta_{15}$ Primary institution

Table reports OLS estimation. Regression includes loan type fixed effects. Dependent variable is the interest rate on the entity's most recent loan. All variables are defined in Table 2. ***, **, * denote significance at 1, 5 and 10 percent level (two-tailed), respectively. 
Table 8

Effect of accrual accounting on interest rates by credit score and relationship length

Panel A: Estimation based on accrual accounting (Accrual) from Table 7, Model 5

\begin{tabular}{lc|cccc} 
& & & \multicolumn{3}{c}{ Credit Score } \\
\cline { 4 - 6 } & \multirow{2}{*}{ Percentile } & & $25^{\text {th }}$ & $50^{\text {th }}$ & $75^{\text {th }}$ \\
\cline { 3 - 5 } & & Value & 38 & 63 & 88 \\
\cline { 3 - 5 } Relationship & $25^{\text {th }}$ & 0.45 & -0.703 & -0.452 & -0.201 \\
& $50^{\text {th }}$ & 0.81 & -0.615 & -0.364 & -0.112 \\
& $75^{\text {th }}$ & 1.14 & -0.534 & -0.283 & -0.032 \\
\hline
\end{tabular}

Panel B: Estimation based on instrumented accrual accounting (Accrual_hat) use

\begin{tabular}{lcccccc} 
& & & \multicolumn{3}{c}{ Credit Score } \\
\cline { 4 - 6 } & \multirow{2}{*}{ Percentile } & & $25^{\text {th }}$ & $50^{\text {th }}$ & $75^{\text {th }}$ \\
\cline { 3 - 5 } & & Value & 38 & 63 & 88 \\
\cline { 3 - 5 } Relationship & $25^{\text {th }}$ & 0.45 & -0.609 & -0.472 & -0.335 \\
& $50^{\text {th }}$ & 0.81 & -0.610 & -0.473 & -0.336 \\
& $75^{\text {th }}$ & 1.14 & -0.611 & -0.474 & -0.337 \\
& & & & & \\
\hline
\end{tabular}

Provides estimate of the effect of accrual accounting $\left(\beta_{1}+\beta_{4}+\beta_{5}\right)$ on the interest rate on the entity's most recent loan for a given Credit score and Relationship based on the following OLS estimation model (Table 7, Model 5): Interest rate $=\alpha$ $+\beta_{1}$ Accrual $+\beta_{2}$ Credit score $+\beta_{3}$ Relationship $+\beta_{4}$ Accrual $\times$ Credit score $+\beta_{5}$ Accrual $\times$ Relationship $+\beta_{6}$ Credit score $\times$ Relationship $+\beta_{7}$ Prime rate $+\beta_{8}$ Duration spread $+\beta_{9}$ Term premium $+\beta_{10}$ Debt to assets $+\beta_{11}$ Fixed rate $+\beta_{12}$ Log total assets $+\beta_{13} \log$ amount $+\beta_{14}$ Collateral $+\beta_{15}$ Primary institution

Regression includes loan type fixed effects. All variables are defined in Table 2 . The values provided with the percentiles are based on sample percentiles of Relationship and Credit score for the cost of debt sample. 
Table 9

Determinants of interest rates partitioned by relationship length

\begin{tabular}{|c|c|c|c|c|}
\hline \multirow[b]{2}{*}{ Independent variables } & \multicolumn{2}{|c|}{ Short Relationship } & \multicolumn{2}{|c|}{ Long Relationship } \\
\hline & Coefficient & Std. error & Coefficient & Std. error \\
\hline Accrual & $-1.647 * * *$ & 0.537 & -0.222 & 0.446 \\
\hline Credit score & $-0.017^{* * *}$ & 0.006 & 0.003 & 0.004 \\
\hline Accrual $\times$ Credit score & $0.019 * *$ & 0.008 & -0.0005 & 0.006 \\
\hline Relationship & -0.033 & 0.072 & $-0.015^{*}$ & 0.009 \\
\hline Prime rate & 0.068 & 0.167 & 0.162 & 0.126 \\
\hline Duration spread & 0.102 & 0.296 & 0.052 & 0.225 \\
\hline Term premium & -0.175 & 0.181 & 0.203 & 0.144 \\
\hline Debt to assets & 0.103 & 0.126 & 0.166 & 0.103 \\
\hline Fixed rate & $1.703^{* * *}$ & 0.348 & $0.772 * * *$ & 0.257 \\
\hline Log total assets & -0.174 & 0.230 & -0.138 & 0.170 \\
\hline Log amount & $-0.674 * * *$ & 0.260 & $-0.840 * * *$ & 0.193 \\
\hline Collateral & $-0.475^{*}$ & 0.268 & -0.011 & 0.189 \\
\hline Primary institution & -0.132 & 0.269 & $0.522 * *$ & 0.251 \\
\hline Intercept & $10.840 * * *$ & 1.437 & $9.534 * * *$ & 1.101 \\
\hline Loan type indicators & Yes & & Yes & \\
\hline $\mathrm{n}$ & \multicolumn{2}{|c|}{598} & \multicolumn{2}{|c|}{591} \\
\hline $\mathrm{R}^{2}$ & \multicolumn{2}{|c|}{0.209} & \multicolumn{2}{|c|}{0.203} \\
\hline F-stat & \multicolumn{2}{|c|}{$8.52^{* * *}$} & \multicolumn{2}{|c|}{$8.11^{* * *}$} \\
\hline \multicolumn{5}{|c|}{$\begin{array}{l}\text { Interest rate }=\alpha+\beta_{1} \text { Accrual }+\beta_{2} \text { Credit score }+\beta_{3} \text { Accrual } \times \text { Credit score }+ \\
\beta_{4} \text { Relationship }+\beta_{5} \text { Prime rate }+\beta_{6} \text { Duration spread }+\beta_{7} \text { Term premium }+\beta_{8} \text { Debt to } \\
\text { assets }+\beta_{9} \text { Fixed rate }+\beta_{10} \text { Log total assets }+\beta_{11} \text { Log amount }+\beta_{12} \text { Collateral }+ \\
\beta_{13} \text { Primary institution } \\
\text { Table reports OLS estimation. Regression includes loan type fixed effects. Dependent } \\
\text { variable is the interest rate on the entity’s most recent loan. Entities are partitioned by } \\
\text { whether the years with their financiers is greater or less than the sample median } \\
\text { respectively. All remaining independent variables are defined in Table } 2 .{ }^{* * *},{ }^{* *}, * \\
\text { denote significance at } 1,5 \text { and } 10 \text { percent level (two-tailed), respectively. }\end{array}$} \\
\hline
\end{tabular}


Table 10

Determinants of interest rates using indicator variables

\begin{tabular}{|c|c|c|c|}
\hline Independent variables & $\mathrm{N}$ & Coefficient & Std. error \\
\hline 1. Accrual $\mathrm{Y} \times$ Credit Score $\mathrm{H} \times$ Relationship $\mathrm{L}$ & 230 & $-1.175^{* * *}$ & 0.315 \\
\hline 2. Accrual $\mathrm{Y} \times$ Credit Score $\mathrm{L} \times$ Relationship $\mathrm{L}$ & 73 & $-1.334 * * *$ & 0.396 \\
\hline 3. Accrual $\mathrm{Y} \times$ Credit Score $\mathrm{H} \times$ Relationship $\mathrm{S}$ & 196 & $-1.171 * * *$ & 0.316 \\
\hline 4. Accrual $\mathrm{Y} \times$ Credit Score $\mathrm{L} \times$ Relationship $\mathrm{S}$ & 98 & $-1.326^{* * *}$ & 0.358 \\
\hline 5. Accrual $\mathrm{N} \times$ Credit Score $\mathrm{H} \times$ Relationship $\mathrm{L}$ & 184 & $-0.995 * * *$ & 0.308 \\
\hline 6. Accrual $\mathrm{N} \times$ Credit Score $\mathrm{L} \times$ Relationship $\mathrm{L}$ & 104 & $-1.016^{* * *}$ & 0.349 \\
\hline 7. Accrual $\mathrm{N} \times$ Credit Score $\mathrm{H} \times$ Relationship $\mathrm{S}$ & 187 & $-1.088^{* * *}$ & 0.302 \\
\hline 8. Accrual $\mathrm{N} \times$ Credit Score $\mathrm{L} \times$ Relationship $\mathrm{S}$ & 119 & -- & -- \\
\hline Prime rate & & 0.126 & 0.105 \\
\hline Duration spread & & 0.072 & 0.186 \\
\hline Term premium & & 0.018 & 0.117 \\
\hline Debt to assets & & 0.138 & 0.082 \\
\hline Fixed rate & & 0.218 & 0.216 \\
\hline Log total assets & & -0.161 & 0.143 \\
\hline Log amount & & -0.745 & 0.161 \\
\hline Collateral & & -0.249 & 0.163 \\
\hline Primary institution & & 0.077 & 0.181 \\
\hline Intercept & & 10.523 & 0.908 \\
\hline Loan type indicators & & Yes & \\
\hline $\mathrm{n}$ & & \multicolumn{2}{|c|}{1,189} \\
\hline $\mathrm{R}^{2}$ & & \multicolumn{2}{|c|}{0.194} \\
\hline F-stat & & \multicolumn{2}{|c|}{13.34} \\
\hline
\end{tabular}

Partitioned Wald Tests of Joint Significance

\begin{tabular}{|c|c|c|c|}
\hline Tests of Accrual Effect (from $N=0$ to $Y=1$ ) for: ${ }^{a}$ & Estimate & F-stat & p-value \\
\hline All firms & & 3.59 & 0.0064 \\
\hline Credit Score H & & 0.26 & 0.769 \\
\hline Credit Score L & & 7.10 & 0.0009 \\
\hline Relationship L & & 0.52 & 0.592 \\
\hline Relationship S & & 6.88 & 0.0011 \\
\hline Credit Score $\mathrm{H} \times$ Relationship $\mathrm{L}$ & -0.180 & 0.47 & 0.495 \\
\hline Credit Score L $\times$ Relationship $\quad$ L & -0.319 & 0.67 & 0.423 \\
\hline Credit Score H $\times$ Relationship $\mathrm{S}$ & -0.082 & 0.09 & 0.762 \\
\hline Credit Score L $\times$ Relationship $S$ & -1.326 & 13.75 & 0.0002 \\
\hline
\end{tabular}




\begin{tabular}{|c|c|c|c|c|}
\hline \multicolumn{2}{|c|}{ Tests of Credit Score Effect (from L to H) for: ${ }^{b}$} & Estimate & F-stat & p-value \\
\hline All firm & & & 3.37 & 0.0095 \\
\hline Accrual & $\mathrm{Y}$ & & 0.23 & 0.797 \\
\hline Accrual & $\mathrm{N}$ & & 6.47 & 0.0016 \\
\hline Relation & & & 0.11 & 0.897 \\
\hline Relation & & & 6.61 & 0.0014 \\
\hline Accrual & $\mathrm{Y} \times$ Relationship $\mathrm{L}$ & 0.159 & 0.21 & 0.644 \\
\hline Accrual & $\mathrm{Y} \times$ Relationship $\mathrm{S}$ & 0.155 & 0.24 & 0.623 \\
\hline Accrual & $\mathrm{N} \times$ Relationship $\mathrm{L}$ & 0.021 & 0.00 & 0.947 \\
\hline Accrual & $\mathrm{N} \times$ Relationship $\mathrm{S}$ & -1.089 & 12.94 & 0.0003 \\
\hline Tests of Relationship Effe & rom $S$ to $L$ ) for: ${ }^{c}$ & Estimate & F-stat & $\mathrm{p}$-value \\
\hline All firm & & & 2.17 & 0.070 \\
\hline Accrual & $\mathrm{Y}$ & & 0.00 & 0.999 \\
\hline Accrual & $\mathrm{N}$ & & 4.34 & 0.0132 \\
\hline Credit S & $\mathrm{H}$ & & 0.06 & 0.943 \\
\hline Credit S & & & 4.25 & 0.0145 \\
\hline Accrual & $\mathrm{Y} \times$ Credit Score $\mathrm{H}$ & -0.004 & 0.00 & 0.987 \\
\hline Accrual & $\mathrm{Y} \times$ Credit Score $\mathrm{L}$ & -0.008 & 0.00 & 0.984 \\
\hline Accrual & $\mathrm{N} \times$ Credit Score $\mathrm{H}$ & 0.094 & 0.12 & 0.734 \\
\hline Accrual & $\mathrm{N} \times$ Credit Score $\mathrm{L}$ & -1.016 & 8.49 & 0.0036 \\
\hline
\end{tabular}

Interest rate $=\alpha+\beta_{1 \text { to7 }}$ Accrual(Y/N) $\times$ Credit score(H/L) $\times$ Relationship(L/S $)+\beta_{8}$ Prime rate $+\beta_{9}$ Duration spread $+\beta_{10}$ Term premium $+\beta_{11}$ Debt to assets $+\beta_{12}$ Fixed rate $+\beta_{13} \log$ total assets $+\beta_{14} \log$ amount $+\beta_{15}$ Collateral $+\beta_{16}$ Primary institution Omitted interaction Accrual_N×Credit score_L×Relationship_S

Table reports OLS estimation. Regression includes loan type fixed effects. Dependent variable is the interest rate on the entity's most recent loan. Accrual $\mathrm{Y}(\mathrm{N})$ is an indicator variable coded one if the firm uses (do not use) accrual accounting, zero otherwise. Credit Score H (L) is an indicator variable coded one if the firm has a credit score equal or above (below) the sample median, zero otherwise. Relationship L (S) is an indicator variable coded one if the firm has a relationship length with their loan provider longer (equal or less) than the sample median, zero otherwise. All remaining independent variables are defined in Table 2.

${ }^{a}$ Estimates the interest rate effect (coefficient, F-stat, and $p$-value) for firms that use accrual accounting (Accrual_Y) versus firms who do not (Accrual_N) based on the model above for the listed sample partitions.

${ }^{\mathrm{b}}$ Estimates the interest rate effect (coefficient, $F$-stat, and $p$-value) for firms that have credit scores equal or above the sample median (Credit score_H) versus firms who do not (Credit score_L) based on the model above for the listed sample partitions.

${ }^{c}$ Estimates the interest rate effect (coefficient, $F$-stat, and $p$-value) for firms that have relationships with their financiers longer than the sample median (Relationship_L) versus firms who do not (Relationship_S) based on the model above for the listed sample partitions. 
Table 11

Determinants of interest rates using indicator variables partitioned by collateral

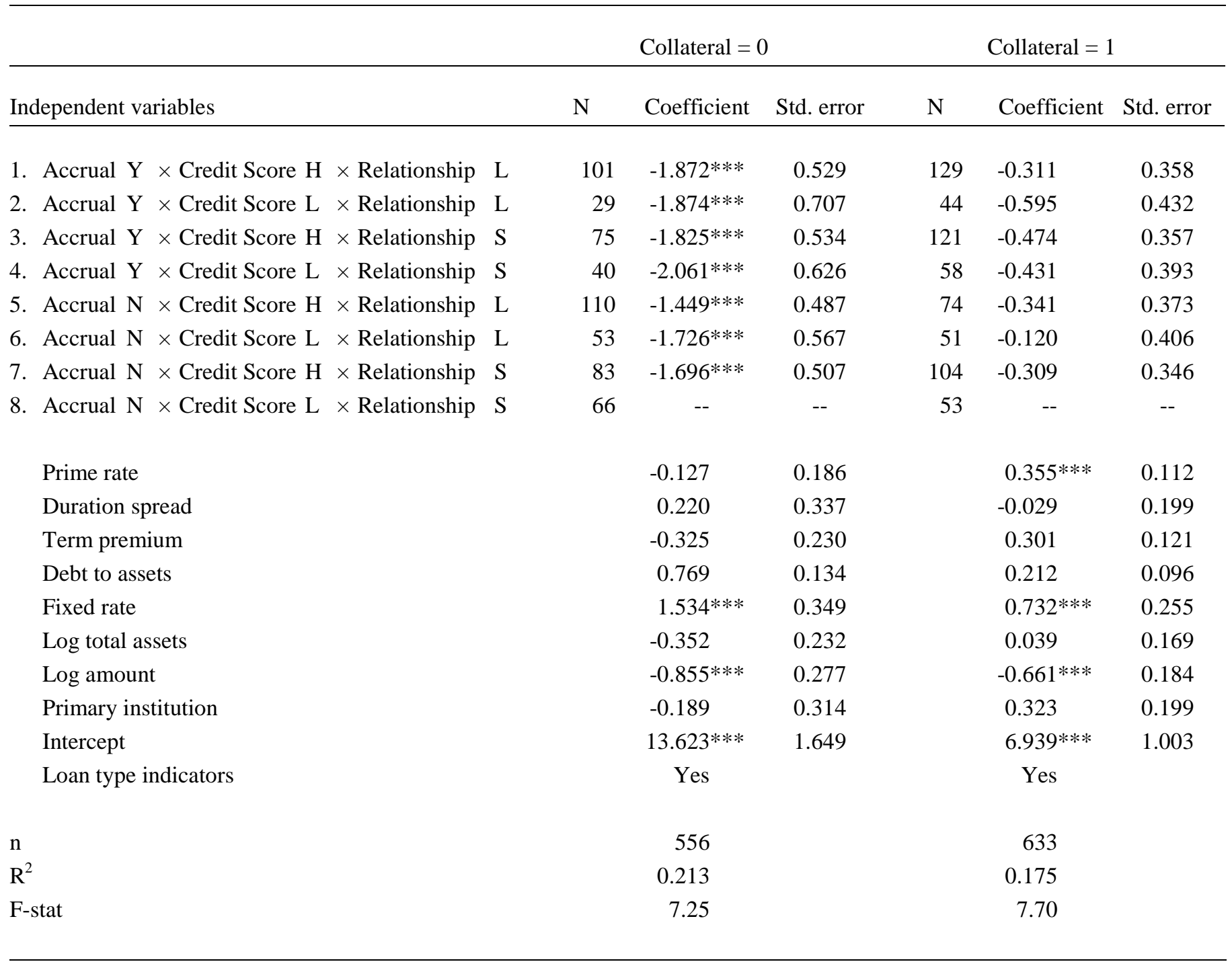

\section{Partitioned Wald Tests of Joint Significance}

\begin{tabular}{|c|c|c|c|c|c|c|}
\hline Tests of Accrual Effect (from $N=0$ to $Y=1$ ) for: ${ }^{a}$ & Estimate & F-stat & p-value & Estimate & F-stat & p-value \\
\hline All firms & & 2.84 & 0.024 & & 0.66 & 0.621 \\
\hline Credit Score L & & 5.41 & 0.0047 & & 1.19 & 0.306 \\
\hline Relationship L & & 0.49 & 0.613 & & 0.63 & 0.531 \\
\hline Credit Score H $\times$ Relationship $\mathrm{L}$ & -0.423 & 0.95 & 0.329 & & 0.01 & 0.923 \\
\hline Credit Score L $\times$ Relationship $\mathrm{L}$ & -0.148 & 0.04 & 0.836 & & 1.24 & 0.266 \\
\hline Credit Score H $\times$ Relationship $\mathrm{S}$ & -0.129 & 0.07 & 0.795 & & 0.32 & 0.573 \\
\hline Credit Score L $\times$ Relationship $\mathrm{S}$ & -2.061 & 10.82 & 0.0011 & & 1.20 & 0.273 \\
\hline
\end{tabular}


Interest rate $=\alpha+\beta_{1 \text { to } 7}$ Accrual $(\mathrm{Y} / \mathrm{N}) \times$ Credit score $(\mathrm{H} / \mathrm{L}) \times$ Relationship(L/S $)+\beta_{8}$ Prime rate $+\beta_{9}$ Duration spread $+\beta_{10}$ Term premium $+\beta_{11}$ Debt to assets $+\beta_{12}$ Fixed rate $+\beta_{13}$ Log total assets $+\beta_{14}$ Log amount $+\beta_{15}$ Primary institution

Omitted interaction Accrual_N×Credit score_L×Relationship_S

Table reports OLS estimation partitioned by whether collateral is provided for the loan. Regression includes loan type fixed effects. Dependent variable is the interest rate on the entity's most recent loan. Accrual $\mathrm{Y}(\mathrm{N})$ is an indicator variable coded one if the firm uses (do not use) accrual accounting, zero otherwise. Credit Score H (L) is an indicator variable coded one if the firm has a credit score equal or above (below) the sample median, zero otherwise. Relationship L (S) is an indicator variable coded one if the firm has a relationship length with their loan provider longer (equal or less) than the sample median, zero otherwise. All remaining independent variables are defined in Table $2 . * * *, * *, *$ denote significance at 1,5 and 10 percent level (two-tailed), respectively.

${ }^{a}$ Estimates the interest rate effect (coefficient, F-stat, and $p$-value) for firms that use accrual accounting (Accrual_Y) versus firms who do not (Accrual_N) based on the model above for the listed sample partitions. 